\title{
Post-licence driver education for the prevention of road traffic crashes (Review)
}

\author{
Ker K, Roberts IG, Collier T, Beyer FR, Bunn F, Frost C
}

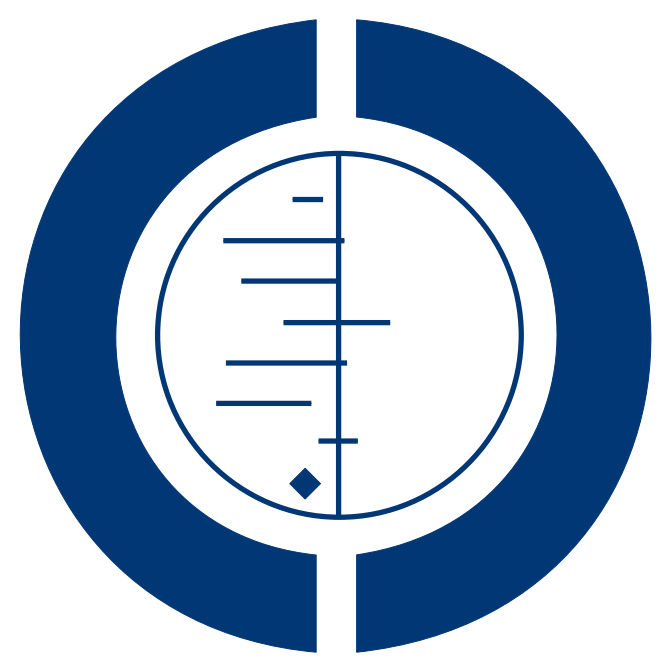

\section{THE COCHRANE COLLABORATION $^{\circledR}$}

This is a reprint of a Cochrane review, prepared and maintained by The Cochrane Collaboration and published in The Cochrane Library 2008, Issue 3

http://www.thecochranelibrary.com

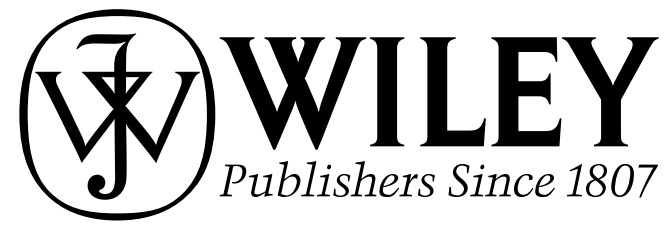

Post-licence driver education for the prevention of road traffic crashes (Review)

Copyright (C) 2008 The Cochrane Collaboration. Published by John Wiley \& Sons, Ltd. 
TABLE OF CONTENTS

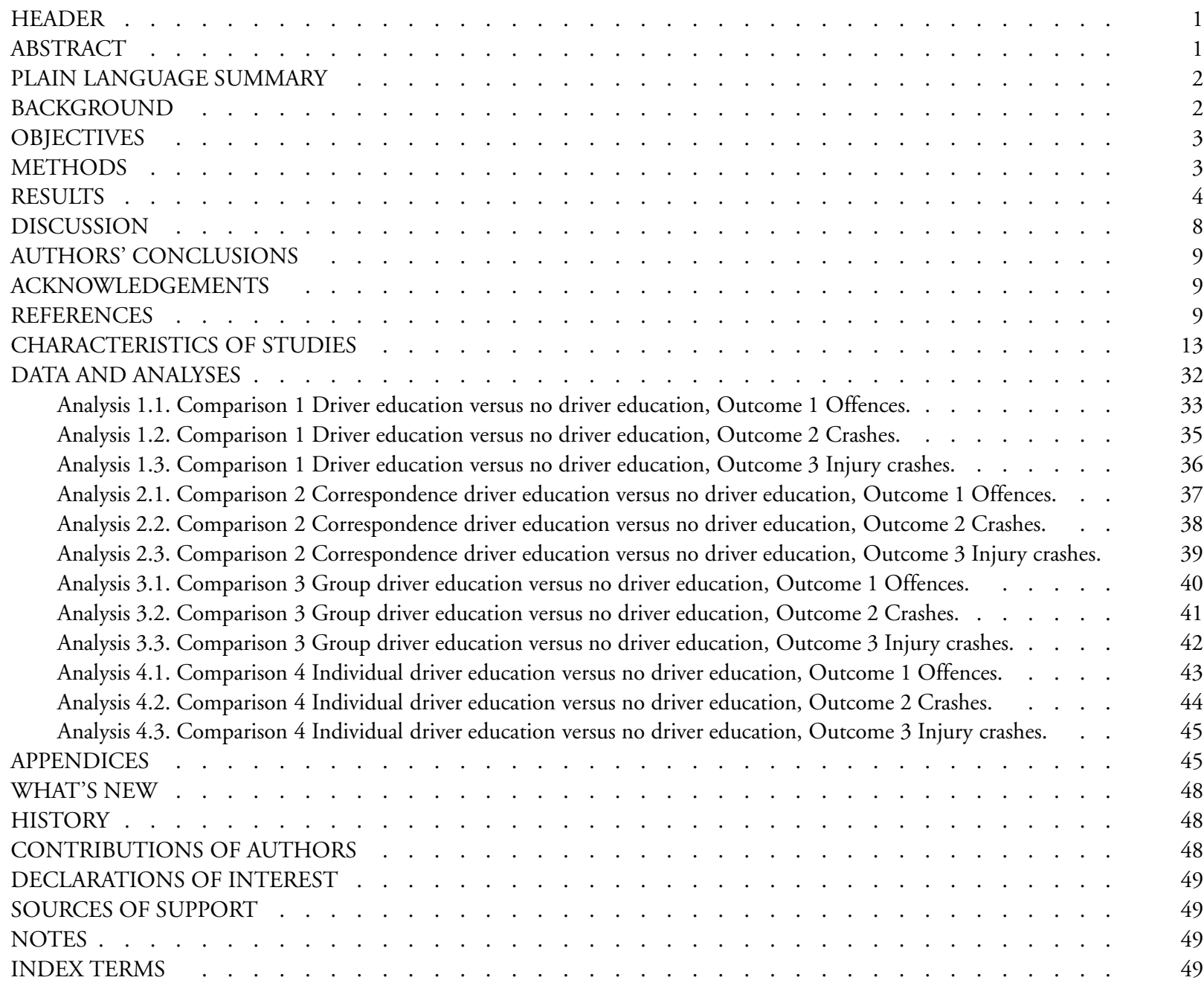




\section{Post-licence driver education for the prevention of road traffic crashes}

Katharine $\operatorname{Ker}^{1}$, Ian G Roberts ${ }^{1}$, Timothy Collier ${ }^{2}$, Fiona R Beyer ${ }^{3}$, Frances Bunn ${ }^{4}$, Chris Frost ${ }^{2}$

${ }^{1}$ Nutrition \& Public Health Intervention Research Unit, London School of Hygiene \& Tropical Medicine, London, UK. ${ }^{2}$ Medical Statistics Unit, London School of Hygiene \& Tropical Medicine, London, UK. ${ }^{3}$ Institute for Health and Society, University of Newcastle, Newcastle upon Tyne, UK. ${ }^{4}$ Centre for Research in Primary and Community Care (CRIPACC), University of Hertfordshire, Hatfield, UK

Contact address: Katharine Ker, Nutrition \& Public Health Intervention Research Unit, London School of Hygiene \& Tropical Medicine, Room 280, North Courtyard, Keppel Street, London, WC1E 7HT, UK. katharine.ker@1shtm.ac.uk.

Editorial group: Cochrane Injuries Group.

Publication status and date: Edited (no change to conclusions), published in Issue 3, 2008.

Review content assessed as up-to-date: 11 March 2003.

Citation: Ker K, Roberts IG, Collier T, Beyer FR, Bunn F, Frost C. Post-licence driver education for the prevention of road traffic crashes. Cochrane Database of Systematic Reviews 2003, Issue 3. Art. No.: CD003734. DOI: 10.1002/14651858.CD003734.

Copyright (C) 2008 The Cochrane Collaboration. Published by John Wiley \& Sons, Ltd.

\section{A B S T R A C T}

\section{Background}

Worldwide, each year over a million people are killed and some ten million people are permanently disabled in road traffic crashes. Post-licence driver education is used by many as a strategy to reduce traffic crashes. However, the effectiveness of post-licence driver education has yet to be ascertained.

\section{Objectives}

To quantify the effectiveness of post-licence driver education in reducing road traffic crashes.

\section{Search strategy}

We searched the following electronic databases: the Cochrane Injuries Group's Specialised Register, Cochrane CENTRAL Register of Controlled Trials, MEDLINE, EMBASE, TRANSPORT (NTIS, TRIS, TRANSDOC, IRRD), Road Res (ARRB), ATRI, National Research Register, PsycInfo, ERIC, C2-SPECTR, Zetoc, SIGLE, Science (and Social Science) Citation Index. We searched the Internet, checked reference lists of relevant papers and contacted appropriate organisations. The search was not restricted by language or publication status. The search was last updated in October 2005.

\section{Selection criteria}

Randomised controlled trials comparing post-licence driver education versus no education, or one form of post-licence driver education versus another.

\section{Data collection and analysis}

Two reviewers independently screened search results, extracted data and assessed methodological trial quality. 


\section{Main results}

We found 24 trials of driver education, 23 conducted in the USA and one in Sweden.

Twenty trials studied remedial driver education. The methodological quality of the trials was poor and three reported data unsuitable for meta-analysis.

Nineteen trials reported traffic offences: pooled relative risk $(R R)=0.96,95 \%$ confidence interval $(95 \% \mathrm{CI})=0.94,0.98)$; trial heterogeneity was significant $(\mathrm{p}=<0.00001)$.

Fifteen trials reported traffic crashes: pooled $\mathrm{RR}=0.98(95 \%$ CI $0.96,1.01)$, trial heterogeneity was not significant $(\mathrm{p}=0.75)$.

Four trials reported injury crashes: pooled $\mathrm{RR}=1.12(95 \%$ CI $0.88,1.41)$, trial heterogeneity was significant $(\mathrm{p}=<0.00001)$.

No one form of education (correspondence, group or individual) was found to be substantially more effective than another, nor was a significant difference found between advanced driver education and remedial driver education. Funnel plots indicated the presence of publication bias affecting the traffic offence and crash outcomes.

\section{Authors' conclusions}

This systematic review provides no evidence that post-licence driver education is effective in preventing road traffic injuries or crashes. Although the results are compatible with a small reduction in the occurrence of traffic offences, this may be due to selection biases or bias in the included trials. Because of the large number of participants included in the meta-analysis (close to 300,000 for some outcomes) we can exclude, with reasonable precision, the possibility of even modest benefits.

\section{PLAIN LANGUAGE SUMMARY}

Strong evidence that advanced and remedial driver education does not reduce road traffic crashes or injuries

Road traffic crashes are a major cause of death and injury worldwide. As drivers' errors are a factor often contributing to traffic crashes, driver education is often used in the belief that this makes drivers safer. Driver education for licensed drivers can be remedial programmes for those with poor driving records, or advanced courses for drivers generally. They can be offered by correspondence, in groups or with individualised training. The review of trials found strong evidence that no type of driver education for licensed drivers leads to a reduction in traffic crashes or injuries.

\section{B A C K G R O U N D}

\section{Description of the condition}

Worldwide, each year over a million people are killed and some ten million people are permanently disabled in road traffic crashes (Murray 1996). For people under 44 years, road traffic crashes are now a leading cause of death and disablement, second only to HIV and AIDS as a cause of death. Furthermore, the evidence suggests that the global epidemic of road traffic injuries is only beginning. Many developing countries are at low levels of motorisation and rates of road traffic injuries can be expected to rise with increasing vehicle use. By 2020, road traffic injuries will, it is estimated, have moved from ninth to third in the world ranking of disease burden (Murray 1996).

\section{Description of the intervention}

Because driver error is a factor in the causation of road traffic crashes, great emphasis has been placed in road safety strategies on efforts to reduce driver error through driver education programmes. Promoting post-licence driver education, enhancing the status of advanced driving qualifications, and encouraging extra training for professional drivers, are key components of the UK government's Road Safety Strategy (DETR 2000). Because many people drive as part of their job, traffic crashes have become a leading cause of occupational injury. In response, some companies invest, at significant cost, in driver education programmes for their employees. Driver education programmes have also been offered to drivers who have committed traffic offences. In some 
cases, drivers attending such programmes are offered lower insurance premiums, or can have citations removed from their driving records, on the assumption that they would be 'safer' drivers after the programme.

In the past few years, however, a different perspective on road safety has emerged that emphasises a systems approach to improving road safety and that questions an over-reliance on driver education. It is well established in industrial safety that the operator is only part of a dynamic system with many components and the operator has inherent limitations and predictable error rates. The systems approach accepts driver limitations and aims to reduce traffic crashes by designing the traffic environment with these limitations in mind. From a systems perspective, it is those that build and operate the road system that have the greatest impact on road safety and attempting to eliminate driver error is considered unlikely to have any significant impact in reducing traffic crashes (Mackay 2001).

\section{Why it is important to do this review}

The theoretical debate about the value of driver education programmes can best be resolved by a consideration of the empirical evidence for their effectiveness. Indeed, the preparation of systematic reviews of the evidence for the effectiveness of road safety interventions has been given a high priority by the World Health Organization in its strategy to reduce traffic injuries. This systematic review was commissioned by the Head of Occupational Safety of AstraZeneca, a large pharmaceutical company, in response to a BMJ editorial (Roberts 2002) calling for road safety policy to be based on evidence. In 2002, the 26,000 AstraZeneca sales representatives drove approximately 514 million $\mathrm{km}$ in total and there were 111 traffic crashes, of which 11 were serious. Road traffic injuries account for 59 per cent of all lost time injuries and are the most common cause of injury within the company. The company had responded by providing driver education programmes and was keen to establish whether this approach was effective.

\section{O B J E C T I V E S}

To quantify the effectiveness of post-licence driver education for reducing road traffic crashes.

\section{METHODS}

\section{Criteria for considering studies for this review}

Types of studies
Randomised controlled trials.

\section{Types of participants}

Motor vehicle drivers (including motorcyclists) of all ages and driving experience who hold a valid driving licence.

\section{Types of interventions}

- Post-licence driver education versus no education.

- One form of post-licence driver education versus another form (i.e. correspondence, group or individual education).

\section{Types of outcome measures}

- Traffic offences.

- Road traffic crashes.

- Injury crashes (fatal and non-fatal injuries caused by a crash).

We did not include driving skills as an outcome measure in this review, because we could not be certain that there was a direct relationship between improvements in driving skills and reduced risk of road traffic crashes.

\section{Search methods for identification of studies}

\section{Electronic searches}

We searched the following databases;

- Cochrane Injuries Group Specialised Register (searched October 14, 2005),

- CENTRAL (The Cochrane Library issue 3, 2005),

- TRANSPORT [includes TRIS, ITRD \& TRANSDOC] (to issue 6, 2005),

- ATRI (Australian Transport Index) (to 2002, Jan),

- MEDLINE (to 2005,October, week 1),

- EMBASE (to 2002, Feb),

- PsychINFO (to 2005, October),

- ERIC (1966 to 2005, October),

- C2-SPECTR (searched on October14, 2005,

The search was not restricted by language or publication status The detailed search strategies are presented in Appendix 1

\section{Searching other resources}

In addition we undertook a general Internet search focusing on the websites of relevant road safety organisations. Reference lists of all potentially eligible studies were examined for other relevant articles and experts in the field were contacted for additional information. 
The original database and website searches were performed during the early months of 2002. The searches were updated in October 2005; further potentially eligible studies have been added as 'studies awaiting assessment'. The process of the inclusion/exclusion of these studies is in progress.

\section{Data collection and analysis}

\section{Selection of studies}

Two reviewers independently examined titles, abstracts and keywords of citations from electronic databases, for eligibility. The full text of all relevant records was obtained and two reviewers independently assessed whether each met the pre-defined inclusion criteria. Disagreement was resolved in consultation with a third reviewer

\section{Data extraction and management}

Two reviewers independently extracted data from each eligible study, using a standard form. Data were extracted on the type of study, characteristics of intervention and control groups, the types of intervention, duration of follow-up and the outcomes evaluated. Where necessary and possible, additional information was sought from researchers involved in the studies.

\section{Assessment of risk of bias in included studies}

Since there is evidence that the quality of allocation concealment particularly affects the results of studies (Schulz 1995), two reviewers scored this quality on the scale used by Schulz (Schulz 1995) as shown below, assigning $\mathrm{C}$ to poorest quality and $\mathrm{A}$ to best quality:

- $\mathrm{C}=$ trials in which concealment was inadequate (such as alternation or reference to case record numbers or to dates of birth)

- $\mathrm{B}=$ trials in which the authors either did not report an allocation concealment approach at all or reported an approach that did not fall into one of the other categories

- $\mathrm{A}=$ trials deemed to have taken adequate measures to conceal allocation (i.e. central randomisation; serially numbered, opaque, sealed envelopes; or other description that contained elements convincing of concealment).

Where the method used to conceal allocation was not clearly reported, attempts were made to contact the author for clarification. We then compared the scores allocated and resolved differences by discussion.

The reviewers were not blinded to the names of the authors, institutions, journal of publication or results of the trials because evidence for the value of this is inconclusive (Berlin 1997).

\section{Assessment of heterogeneity}

Heterogeneity between trials was assessed using a chi-squared test, where $P$ less than or equal to 0.05 was taken to indicate significant heterogeneity.

\section{Assessment of reporting biases}

Selection (publication) bias was investigated using Egger's weighted regression method.

\section{Data synthesis}

The relative risks and 95\% confidence intervals were calculated for each trial and were pooled using a random effects model. A number of studies included in the meta-analysis reported either the risk of drivers having one or more crashes/offences or the rate of crashes/offences in the follow-up period. In order to pool the results across all studies it was necessary to translate the rate statistic into a risk of having one or more failures. Assuming that the number of crashes/offences follow a negative binomial (over-dispersed Poisson) distribution, explicit formulae (McCullagh 1989) link the expected rate with the expected risk, provided that the degree of over-dispersion is known. For crashes, analysis suggested that there was little or no over-dispersion, whilst for offences, analysis suggested an over-dispersion parameter of 0.37 . These estimates of over-dispersion were used to estimate expected risks where only rates were given. The variance of the log risk ratio was calculated via the standard formula.

When the results from more than one intervention group were reported, data were combined from all educational intervention groups as appropriate.

\section{RE S U L T S}

\section{Description of studies}

See: Characteristics of included studies; Characteristics of excluded studies.

\section{Results of the search}

The combined search strategy identified approximately 1300 published and unpublished studies, of which 87 were deemed to be potentially relevant, based on the title or abstract. After a full text review, 24 trials were judged to meet the inclusion criteria, including more than 300,000 randomised participants. 


\section{Included studies}

All of the trials were carried out in the USA, with the exception of Nolen 2002, which was conducted in Sweden.

The publication date ranged over a 40-year time span, from 1962 to 2002 .

Sample sizes varied from 105 to over 95,068 drivers. Eighteen trials recruited more than 1000 participants.

\section{Participants}

Trials of programmes were eligible if they incorporated an education component aimed at the motor vehicle driver. Two distinct forms of education were identified. The first of these was remedial driver education, aimed at drivers who had poor previous driving records in terms of the number of prior crashes and/or offences. This type of education would tend to emphasise developing skills and knowledge to improve the drivers' behaviour to prevent recidivism and promote safety. The second form, was advanced driver education, aimed at the 'general' driver, that would build upon the initial education given to drivers before obtaining a licence. Emphasis would be placed on the further development of driving skills for the maintenance and improvement of good driving.

Of the included trials, four investigated the effectiveness of advanced driver education (McCoy 1993; Nolen 2002; Schuman 1971; Stoke 1980). The remaining 20 trials studied remedial driver education (Coppin 1962; Coppin 1965; Fuchs 1980; Harano 1972; Helander 1984a; Helander 1984b; Kadell 1987a; Kadell 1987b; Kaestner 1967; Kaestner 1975; Kaestner 1980; Lynn 1982a; Lynn 1982b; Lynn 1982c; Marsh 1971; Marsh 1978; Peck 1980; Prothero 1978; Ratz 1978; Raub 1999).

One trial targeted 'older' drivers between the ages of 65 and 88 (McCoy 1993), and one recruited senior pupils of a High School ( Schuman 1971). Most of the trials did not appear to impose criteria regarding participants age or gender when recruiting. Participants were all full driving licence holders, hence individuals were at least 16 years of age. Four trials did have age as a recruitment criteria; Harano 1972 recruited drivers between the ages of 17 and 50, Kaestner 1967 male drivers between 16 and 64 years, Marsh 1971 drivers between 16 and 60 years and Nolen 2002 focused on 'younger' drivers between 18 and 24 years.

\section{Intervention characteristics}

The types of education interventions ranged from an advisory letter or driving manual sent out to participants, to a formal education course, sometimes involving multiple sessions with instructors at designated centres, delivered in an individual or a group setting. All interventions involved the transfer of information aimed at improving driving performance and safety.

Three distinct varieties of driver education were identified for inclusion into the analysis.
- Correspondence education. Programmes were considered to be 'correspondence education' if they did not involve direct contact with an instructor. Educational information was usually contained within a manual or letter sent to drivers.

- Group education. Programmes were classed as 'group education' if information was delivered to a group of drivers, hence the content was not designed around the requirement of an individual participant. These generally took the form of one or more pre-organised sessions led by an instructor.

- Individual education. Programmes were classed as 'individual education' if they consisted of a session in which the participating driver received education delivered on a one-onone basis with an instructor. The content of the information given could often be geared to suit the specific requirements of the driver attending.

Nine trials compared correspondence driver education (i.e. advisory letter, manual) with a no-education control (Helander 1984a; Helander 1984b; Kadell 1987a; Kadell 1987b; Kaestner 1975; Lynn 1982a; Marsh 1971; Marsh 1978; Stoke 1980).

Sixteen trials compared group driver education versus a no-education control (Coppin 1962; Coppin 1965; Harano 1972; Kadell 1987a; Kaestner 1975; Kaestner 1980; Lynn 1982b; Marsh 1971; Marsh 1978; McCoy 1993; Nolen 2002; Peck 1980; Prothero 1978; Ratz 1978; Raub 1999; Schuman 1971).

Seven trials compared individual driver education with a no-education control (Fuchs 1980; Helander 1984a; Helander 1984b; Kaestner 1967; Lynn 1982c; Marsh 1971; Ratz 1978).

\section{Outcome measures}

Length of follow-up ranged from 6 to 24 months. Fourteen studies reported data on both subsequent crashes and traffic offences of the study participants (Coppin 1962; Coppin 1965; Fuchs 1980; Harano 1972; Helander 1984a; Helander 1984b; Kadell 1987a; Kadell 1987b; Kaestner 1967; Marsh 1971; Marsh 1978; Peck 1980; Prothero 1978; Stoke 1980).

Five reported data solely for subsequent traffic offences (Kaestner 1975; Lynn 1982a; Lynn 1982b; Lynn 1982c; Raub 1999), and one presented data for subsequent crashes only (Schuman 1971). Seven studies reported data on subsequent injury crashes (Kadell 1987a; Kadell 1987b; Lynn 1982a; Lynn 1982b; Lynn 1982c; Nolen 2002; Ratz 1978).

Kaestner 1980 used subsequent traffic offences and crashes as outcome measures. However, the data were not reported separately. Instead, the study provided figures on the number of 'successes' in each study group, defined as drivers who did not incur subsequent crashes or traffic offences in the follow-up period.

McCoy 1993 was the only study which did not use either crashes or traffic offences as an outcome measure. Instead changes in driving behaviour were measured with a driver performance measurement (DPM) test score developed at Michigan State University. 
For a more detailed description of individual studies, see Table of included studies.

\section{Risk of bias in included studies}

The methodological quality of included trials was generally poor. Using predefined criteria (Schulz 1995), the quality of allocation concealment was adequate in one, unclear in 13 and inadequate in 10 trials. Blinding of outcome assessment was adequate in 11 trials. Eight trials reported that an intention-to-treat analysis was used.

Coppin 1962

This study was reported as randomised but the methods of randomisation and allocation concealment were not described. Participants who did not attend the meeting (one in three of those assigned) were not included in the analysis. No information was reported on loss to follow-up.

Coppin 1965

This study was reported as randomised but the methods of randomisation and allocation concealment were not described. No information was reported on loss to follow-up.

Fuchs 1980

The control group consisted of a randomly selected ten per cent of the target group, by selecting every tenth name. Allocation concealment was inadequate. A number of drivers were found to have been 'mis-assigned' and were not included in the analysis. No information was reported on loss to follow-up.

Harano 1972

Participants were assigned to groups by traffic court judges, who used an odd/even alternation method based on the last digit of each drivers' licence number. Allocation concealment was inadequate. Despite the planned randomisation, judges exercised selectivity in assignment as they were reluctant to assign drivers with the poorest driving records to the control group. No information was reported on loss to follow-up.

Helander 1984a

Driver record printouts of eligible participants were sequentially sorted into four baskets, each representing a treatment condition. Allocation concealment was unclear and no information was reported on loss to follow-up.

Helander 1984b

Driver record printouts of eligible participants were sequentially sorted into three baskets, each representing a treatment condition. Allocation concealment was unclear and no information was reported on loss to follow-up.

Kadell 1987a

Printouts were sequentially sorted into four baskets by the scheduling unit. Allocation concealment was unclear and no information was reported on loss to follow-up.

Kadell 1987b

Participants were assigned on the basis of the last two digits of their driving licence number. Allocation concealment was inadequate and no information was reported on loss to follow-up.

Kaestner 1967

Participants were assigned on an odd/even basis, further details were not reported. Allocation concealment was inadequate. Issues such as court recommended suspensions, mandatory suspensions, financial responsibility suspensions caused assignment problems. Approximately nine per cent of participants were lost to followup.

\section{Kaestner 1975}

This study was reported as randomised but the methods of randomisation and allocation concealment were not described. A number of the originally assigned participants were dropped from the study, and replaced with randomly chosen eligible drivers. Twenty-eight of the total 960 participants did not have their records analysed, as they were not resident in the study area for the entire follow-up period.

\section{Kaestner 1980}

Participants were assigned on the basis of the last two digits of their driving licence number; numbers 00-33, 34-66, 67-99 were assigned to the three study groups accordingly. Allocation concealment was inadequate. During the course of the study, nonrandom attrition occurred between all three groups, participants who received treatment that differed from that determined by the original assignment, were deleted from the study. A difficulty arose regarding participants who left the study area during the one year follow-up period, as their driving records after leaving were not available. Nevertheless, they remained in the study.

\section{Lynn 1982a}

It was reported that participants were assigned on the basis of 'the millisecond of entry on the driving record' of the offence making them eligible for selection, further details were not provided. Allocation concealment was unclear. Assignments were equally distributed across a 12-month period. No information was reported on loss to follow-up.

Lynn 1982b

It was reported that participants were assigned on the basis of 'the millisecond of entry on the driving record' of the offence making them eligible for selection, further details were not provided. Allocation concealment was unclear. Assignments were equally distributed across a 12-month period. No information was reported on loss to follow-up.

Lynn $1982 \mathrm{c}$

It was reported that participants were assigned on the basis of 'the millisecond of entry on the driving record' of the offence making them eligible for selection, further details were not provided. Allocation concealment was unclear. Assignments were equally distributed across a 12-month period. No information was reported on loss to follow-up.

Marsh 1971

Participants were assigned on the basis of the last two digits of their 
driving licence number. Allocation concealment was inadequate. Approximately 50 per cent of participants assigned to the group meetings did not attend. Their records were, however, kept in the analysis. No information was reported on loss to follow-up.

Marsh 1978

Assignment was conducted according to a predetermined sequence that was different for each field office, the treatment assignment sequence was developed using a table of random numbers. Allocation concealment was unclear. Attempts were made to ensure that participants were unaware that they were participating in a trial. A number of participants received the incorrect treatment. However, they were analysed according to the groups into which they were assigned. Of the total 17,780 drivers originally assigned, 0.7 per cent were lost to follow-up.

McCoy 1993

This study was reported as randomised but the methods of randomisation and allocation concealment were not described. Drivers had been invited to participate in the trial and paid for their time. Ninety-four of the original sample of 105 completed the study and some mis-assignment between groups occurred. The driving performance of the participants was evaluated using driver performance measurement (DPM) scores, not a direct measure of crash experience.

Nolen 2002

Assignment was determined by alternation and drawing lots. Allocation concealment was unclear. Participants responded to an invitation to attend a driver education course. Twenty-nine per cent of participants were lost to follow-up.

Peck 1980

Participants were assigned on the basis of the terminal digit of their driving licence number. Allocation concealment was inadequate. Participants were recruited only from courts who had previously agreed to take part in the trial. A degree of mis-assignment did occur, with 32 per cent of drivers who should have been in the control group incorrectly receiving the treatment.

Prothero 1978

Participants were randomly assigned by a court hearing officer. Allocation concealment was inadequate. Fifteen per cent of the original sample was not included in the final analysis, due to missing driving records and failure of a number of participants to complete treatment.

\section{Ratz 1978}

Participants were assigned on the basis of the terminal digits of their driving licence number. Allocation concealment was inadequate and no information was reported on loss to follow-up.

Raub 1999

Clerks in Cook County Traffic Court placed requests alternately into two bins. The clerks did not know why the applications were separated. Allocation concealment was adequate and no information was reported on loss to follow-up.

Schuman 1971

The participants in the treatment and control groups were ran- domly selected from a senior class list of a Michigan High School. Allocation concealment was unclear and no information was reported on loss to follow-up.

Stoke 1980

Each month, for a total of seven months, a list of eligible drivers was produced. From this, 'every nth individual' was selected and then systematically assigned to one of four groups. Allocation concealment was inadequate and no information was reported on loss to follow-up.

\section{Effects of interventions}

The search process identified 24 trials meeting the inclusion criteria. Three of these reported outcome data unsuitable for this metaanalysis and were not considered further (Harano 1972; Kaestner 1980; McCoy 1993). The analysis was based on 21 trials, providing data on 309,624 participants. Of these, three involved advanced driver education and the remaining 18 investigated remedial driver education, providing data on approximately 49,401 and 260,223 drivers, respectively.

Eight trials compared a no-education control with more than one form (correspondence, group, individual) of driver education, and have been included in more than one comparison group.

\section{Traffic offences}

Nineteen trials compared the effectiveness of any form of driver education with no education in reducing traffic offences. The pooled relative risk was 0.96 (95\% CI 0.94,0.98). There was significant heterogeneity between trials (chi-square $=71.67, \mathrm{df}=18, \mathrm{P}=$ $<0.00001)$.

- For the 18 trials of remedial driver education, the pooled relative risk was 0.96 (95\% CI 0.94, 0.98). There was significant heterogeneity between trials (chi-square $=71.67, \mathrm{df}=17, \mathrm{P}=$ $<0.00001)$.

- For the one trial of advanced driver education the relative risk was 0.98 (95\% CI 0.93, 1.03).

Nine trials compared correspondence driver education with no education. The pooled relative risk was 0.98 (95\% CI 0.97, 0.99). There was no significant heterogeneity between trials (chi-square= 7.71, $\mathrm{df}=8, \mathrm{P}=0.46$ ).

- For the eight trials of remedial driver education by correspondence the pooled relative risk was 0.98 (95\% CI 0.97 , 0.99). There was no significant heterogeneity between trials (chisquare=7.67, $\mathrm{df}=7, \mathrm{P}=0.36$ ).

- For the one trial of advanced driver education by correspondence the relative risk was 0.98 (95\% CI 0.93, 1.03).

Eleven trials compared group driver education with no education. The pooled relative risk was 0.95 (95\% CI 0.92,0.97). There was significant heterogeneity between trials (chi-square $=23.26, \mathrm{df}=10$, $\mathrm{P}=0.0098)$. All 11 trials were of remedial driver education. 
Seven trials compared individual driver education with no education. The pooled relative risk was 0.95 (95\% CI 0.91,1.00). There was significant heterogeneity between trials (chi-square= $46.09, \mathrm{df}=6, \mathrm{P}=<0.00001$ ). All seven trials were of remedial driver education.

\section{Traffic crashes}

Fifteen trials compared the effectiveness of any form of driver education with no education for preventing crashes. The pooled relative risk was 0.98 (95\% CI 0.96 to 1.01). There was no significant heterogeneity between trials (chi-square $=10.19, \mathrm{df}=14, \mathrm{P}=0.75$ ).

- For the 13 trials of remedial driver education, the pooled relative risk was 0.98 ( $95 \%$ CI 0.96 to 1.01 ). There was no significant heterogeneity between trials (chi-square $=9.84, \mathrm{df}=12$, $\mathrm{P}=0.63)$.

- For the two trials of advanced driver education, the pooled relative risk was 0.99 ( $95 \%$ CI 0.93 to 1.05 ). There was no significant heterogeneity between trials (chi-square $=0.34, \mathrm{df}=1$, $\mathrm{P}=0.56)$.

Seven trials compared correspondence driver education with no education. The pooled relative risk was 0.98 ( $95 \%$ CI 0.95 to 1.01 ). There was no significant heterogeneity between trials (chi-square= 4.14, $\mathrm{df}=6, \mathrm{P}=0.66$ ).

- For the six trials of remedial driver education by correspondence, the pooled relative risk was 0.97 (95\% CI 0.93 to 1.02$)$. There was no significant heterogeneity between trials (chi-square $=4.03, \mathrm{df}=5, \mathrm{P}=0.55$ ).

- For the one trial of advanced driver education by correspondence, the relative risk was 0.98 (95\% CI 0.93 to 1.05 ).

Ten trials compared group driver education with no education. The pooled relative risk was 0.97 (95\% CI 0.93 to 1.02). There was no significant heterogeneity between trials (chi-square $=5.14$, $\mathrm{df}=9, \mathrm{P}=0.82$ )

- For the eight trials of remedial group driver education the pooled relative risk was 0.98 (95\% CI 0.93 to 1.02). There was no significant heterogeneity between trials (chi-square $=4.74, \mathrm{df}=$ 7, $\mathrm{P}=0.69$ ).

- For the two trials of advanced group driver education the pooled relative risk was 0.92 ( $95 \%$ CI 0.73 to 1.17$)$. There was no significant heterogeneity between trials (chi-square $=0.21, \mathrm{df}=$ $1, \mathrm{P}=0.64)$.

Six trials compared individual driver education with no education. The pooled relative risk was 0.99 (95\% CI 0.96 to 1.03). There was no significant heterogeneity between trials (chi-square $=5.07$, $\mathrm{df}=5, \mathrm{P}=0.41$ ). All six trials were of remedial driver education.

\section{Injury crashes}

Four trials reporting injury crashes presented data suitable for this meta-analysis and compared the effectiveness of driver education with no education. The pooled relative risk was 1.12 (95\% CI 0.88 to 1.41$)$. There was significant heterogeneity between trials (chi-square $=27.10, \mathrm{df}=3, \mathrm{P}=<0.00001$ ).

- For the three trials of remedial driver education the pooled relative risk was $1.17(95 \% \mathrm{CI} 0.89,1.54)$. There was significant heterogeneity between trials (chi-square $=23.70, \mathrm{df}=2, \mathrm{P}=$ $<0.00001)$.

- For the one trial of advanced driver education the relative risk was 0.94 (95\% CI 0.74 to 1.20 ).

One trial compared correspondence remedial driver education with no education. The relative risk was 0.94 (95\% CI 0.81 to 1.09).

Three trials compared group driver education with no education. The pooled relative risk was 1.02 (95\% CI 0.93 to 1.13 ). There was no significant heterogeneity between trials (chi-square $=0.11$, $\mathrm{df}=2, \mathrm{P}=0.57)$.

- For the two trials of remedial group driver education the pooled relative risk was 1.04 (95\% CI 0.94 to 1.16). There was no significant heterogeneity between trials (chi-square $=0.53, \mathrm{df}=$ $1, \mathrm{P}=0.47)$.

- For the one trial of advanced group driver education the relative risk was 0.94 (95\% CI 0.74 to 1.20$)$.

One trial compared individual remedial driver education with no education. The relative risk was 1.18 (95\% CI 1.00 to 1.38 ). Selection bias was assessed using Egger's weighted regression method.

- For the traffic offences outcome, there was evidence of small study effects (Egger's test bias coefficient $=-1.69(95 \% \mathrm{CI}$ 3.14 to -0.23$) \mathrm{P}=0.03)$.

- For the traffic crashes outcome, there was evidence of small study effects (Egger's test bias coefficient $=-0.99(95 \% \mathrm{CI}-1.81$ to -0.17$) \mathrm{P}=0.02)$.

- For the traffic injury crashes outcome, there was no evidence of selection bias (Egger's test bias coefficient $=-0.53$ (95\% CI -11.26 to 10.19$) \mathrm{P}=0.88$ ).

Six potentially relevant trials are currently awaiting assessment (Ayers 1980; Finigan 1995; O’Brien 1981; PLCRES 1976-81; Salzberg 1978; Ulmer 1979), the full text of which were not available to us at the time of analysis. We aim to incorporate these studies during the review's subsequent update.

\section{DISCUSSION}

This systematic review of randomised controlled trials provides no evidence that post-licence driver education programmes are effective in preventing road traffic injuries or crashes. Although the results are compatible with a small reduction in the occurrence of traffic offences, this may be due to publication or other selection biases, or else to bias in the included trials. Because of the large 
number of randomised participants included in the meta-analysis (close to 300,000 for some outcomes), we can exclude, with reasonable precision, the possibility of even modest benefits.

Publication and other selection biases are a potential threat to validity in all systematic reviews, and in this review there was evidence of funnel plot asymmetry using both graphical and statistical methods. From the graphical presentations it would appear that any such bias would lead to an overestimation of the beneficial effect of driver education. Inadequate allocation concealment, lack of blinding of outcome assessment, and large losses to followup in many of the include trials also call into question the validity of the observed reduction in traffic offences following driver education. Although we pooled the data in a random effects metaanalysis, there was significant heterogeneity in several of the metaanalyses, and these should be interpreted with particular caution. The observed heterogeneity may be due to differences in the study populations, in the types of education programmes, or in the way that the outcome data were defined and collected.

The included trials ranged over a 40 -year publication time span, all but four were of remedial driver education and only one was conducted outside the USA. As a result, it may not be appropriate to generalise from this systematic review and make inferences about the effectiveness of present-day driver education programmes. On the other hand, we can reasonably conclude that the effectiveness of current driver education programmes is as yet unproven, an observation that casts doubt on the wisdom of placing undue emphasis on this approach in current road safety policy.

Our review was commissioned by AstraZeneca - a company that provides driver education programmes for most of its driving employees in an effort to reduce the occurrence of occupational road traffic injuries - and it is important to consider the implications of our results for this policy. Whilst we cannot claim that our results show that this policy is ineffective, we would argue that, in the light of the evidence from previous trials, unrealistic expectations about the effectiveness of driver education must be avoided. We would recommend that the company pursue other approaches to reducing road traffic injuries amongst its employees. For example, reducing risk exposure by eliminating all unnecessary car journeys, encouraging the use of technologies such as teleconferencing as alternatives to travel, and using safer modes such as train travel (HSE 2002), whenever possible.

\section{AUTHORS' CONCLUSIONS}

\section{Implications for practice}

There is no evidence that current post-licence driver education is an effective measure for the reduction of road traffic crashes. Hence, it can be considered unwise to place undue emphasis on such an approach in road safety policy. Emphasis, instead, might be more appropriately placed on other strategies such as reducing drivers' crash risk exposure by eliminating unnecessary car journeys.

\section{Implications for research}

In our search for studies of post-licence driver education we found just three randomised controlled trials conducted within the last 15 years suitable for inclusion in this systematic review, and just one trial conducted outside the USA. Further high-quality randomised controlled trials with injury outcomes are required in a variety of countries, to determine the effectiveness of current post-licence driver education.

\section{ACKNOWLEDGEMENTS}

Many thanks to Johan Collander and Mirna Holle for help with translation and to the authors who provided us with further details of their studies. Also, thanks to Chris Frost for his advice on the statistical analyses.

\section{RE F E R E N C E S}

\section{References to studies included in this review}

Coppin 1962 \{published data only\}

Coppin RS. A controlled evaluation of group driver improvement meetings. Traffic Safety 1962;6(3):17-23.

Coppin 1965 \{published data only\}

* Coppin RS, Marsh WC, Peck RC. A re-evaluation of group driver improvement meetings. State of California, Department of Motor Vehicles 1965; Vol. Report no. 17.

Marsh WC, Coppin RS, Peck RC. A reevalution of group driver improvement meetings. Highway Safety Research Record 1967;163: $120-131$.
Fuchs 1980 \{published data only\}

Fuchs C. Wisconsin Driver Improvement Program: A TreatmentControl Evaluation. Journal of Safety Research 1980;12(3):107-114.

Harano 1972 \{published data only\} Harano RM. The effectiveness of a uniform traffic school curriculum for negligent drivers. Accident Analysis \& Prevention 1972;4(1):13-45.

\section{Helander 1984a \{published data only\}}

Helander CJ. Intervention strategies for accident-involved drivers: An experimental evaluation of current Californian policy and alternatives (Standard criteria). Journal of Safety Research 1984;15 (1):23-40. 


\section{Helander 1984b \{published data only\}}

Helander CJ. Intervention strategies for accident-involved drivers: An experimental evaluation of current Californian policy and alternatives (Expanded criteria). Journal of Safety Research 1984;15 (1):23-40.

\section{Kadell 1987a \{published data only\}}

* Kadell D. Traffic safety impacts of the home instruction/point reduction incentive (HI/PRI) program (Negligent operator component). Journal of Safety Research 1987;18:149-178. Kadell DJ. The traffic safety impact of driver improvement countermeasures targetting 55-mph speed limit compliance. State of California, Department of Motor Vehicles 1984.

\section{Kadell 1987b \{published data only\}}

Kadell D. The traffic safety impact of driver improvement countermeasures targetting 55-mph speed limit compliance. State of California, Department of Motor Vehicles 1984.

* Kadell D. Traffic safety impacts of the home instruction/point reduction incentive (HI/PRI) program (Speed component). Journal of Safety Research 1987;18(4):149-178.

\section{Kaestner 1967 \{published data only\}}

Kaestner N, Syring EM. Accident and violation reduction through brief driver improvement interviews. Traffic Safety Research Review 1967;11(4):121-124.

\section{Kaestner 1975 \{published data only\}}

Kaestner N, Speight L. Successful alternatives to license suspension: The Defensive Driving Course and the probationary license. Journal of Safety Research 1975;7:56-66.

\section{Kaestner 1980 \{published data only\}}

Kaestner N. Driver improvement schools - An evaluation of two programs. Oregon Motor Vehicles Division, Department of Transportation 1980

\section{Lynn 1982a \{published data only\}}

* Lynn C. An evaluation of the impact of the Virginia driver improvement program on negligent driving: 12 month report. Virginia Department of Transportation Safety 1982; Vol. VHTRC 82-R43.

Lynn C. An evaluation of the impact of the Virginia driver improvement program on negligent driving: 24 month report.

Virginia Department of Transportation Safety 1982; Vol. VHTRC 83-R6.

Lynn C. An evaluation of the the short-term effects of the Virginia driver improvement program: interim report. Virginia Department of Transportation Safety 1981; Vol. VHTRC 81-R46.

\section{Lynn 1982b \{published data only\}}

* Lynn C. An evaluation of the impact of the Virginia driver improvement program on negligent driving: 12 month report. Virginia Department of Transportation Safety 1982; Vol. VHTRC 82-R43.

Lynn C. An evaluation of the impact of the Virginia driver improvement program on negligent driving: 24 month report. Virginia Department of Transportation Safety 1982; Vol. VHTRC 83-R6.

Lynn C. An evaluation of the the short-term effects of the Virginia driver improvement program: interim report. Virginia Department of Transportation Safety 1981; Vol. VHTRC 81-R46.
Lynn 1982c \{published data only\}

* Lynn C. An evaluation of the impact of the Virginia driver improvement program on negligent driving: 12 month report. Virginia Department of Transportation Safety 1982; Vol. VHTRC 82-R43.

Lynn C. An evaluation of the impact of the Virginia driver improvement program on negligent driving: 24 month report. Virginia Department of Transportation Safety 1982; Vol. VHTRC 83-R6.

Lynn C. An evaluation of the the short-term effects of the Virginia driver improvement program: interim report. Virginia Department of Transportation Safety 1981; Vol. VHTRC 81-R46.

\section{Marsh 1971 \{published data only\}}

* Marsh WC. Modifying negligent driving behaviour: evaluation of selected driver improvement techniques. State of California, Department of Motor Vehicles 1971; Vol. Report no. 36. Marsh WC. Modifying negligent driving behaviour: evaluation of selected driver improvement techniques, a second year follow-up. State of California, Department of Motor Vehicles 1973.

\section{Marsh 1978 \{published data only\}}

Marsh WC. Educational approaches the driver improvement: an experimental evaluation with negligent drivers. State of California, Department of Motor Vehicles 1978; Vol. Research Report no. 66.

\section{McCoy 1993 \{published data only\}}

McCoy PT, Tarawneh MS, Bishu RR, Ashman RD, Foster BG. Evaluation of countermeasures for improving driving performance of older drivers. Transportation Research Record 1993;1405:72-80.

Nolen 2002 \{published data only\}

Nolen S, Engstrom I, Folkesson, Jonsson A, Meyer B, Nygard B. PILOT - Further education of young drivers. Final report [PILOT - Vidareutbildning av unga bilforare. Slutrapport]. Swedish National Road and Transport Research Unit (VTI) 2002; Vol. rapport 457.

Peck 1980 \{published data only\}

Peck RC, Kelsey SL, Ratz M, Sherman BR. The effectiveness of accredited traffic violator schools in reducing accidents and violations. Journal of Safety Research 1980;12(2):68-77.

\section{Prothero 1978 \{published data only\}}

Prothero JC. Evaluation of an experimental treatment for problem drivers. Human Factors 1978;20(4):489-493.

\section{Ratz 1978 \{published data only\}}

Ratz M. The effects of a traffic safety film or a drive test with counseling session for renewal drivers license applicants with poor prior records. State of California, Department of Motor Vehicles 1978; Vol. Research report 64.

Raub 1999 \{published data only\}

Raub RA, Wark RI, Reischl BE, Lucke RE. Recorded traffic offenses of graduates of traffic safety school, Cook County, Illinois. Transportation Research Record 1999;1693:18-24.

Schuman 1971 \{published data only\}

Schuman SH, McConochie R, Pelz DC. Reduction of young driver crashes in a controlled pilot study: Two year follow-up in one Michigan high school. JAMA 1971;218(2):233-237. 
Stoke 1980 \{published data only\}

Stoke CB. Effectiveness of written tests of drivers' knowledge of rules of the road. Transportation Research Record 1980;782:1-8.

\section{References to studies excluded from this review}

\section{Campbell 1959 \{published data only\}}

Campbell BJ. The effects of driver improvement actions on driving behavior. In: Haddon W, Suchman EA, Klein D editor(s). Research in Accident Prevention. Harper \& Row, 1964

* Campbell BJ. The effects of driver improvement actions on driving behavior. Traffic Safety 1959;3(3):19-31.

\section{Carcary 2001 \{published data only\}}

Carcary WB, Power KG, Murray FA. The new driver project. Changing driving beliefs, attitudes and self-reported driving behaviour amongst young drivers through classroom-based pre and post driving test interventions. Scottish Executive Central Research Unit 2001

Gregersen 1996 \{published data only\}

Gregersen NP. Young drivers' overestimation of their own skill - an experiment on the relation between training strategy and skill. Accident Analysis and Prevention 1996;28(2):243-250.

Henderson 1967 \{published data only\}

Henderson HL, Kole T. New Jersey Driver Improvement Clinics: An Evaluation Study. Traffic Safety Research Review 1967;11(4): $98-105$.

Kaestner 1968 \{published data only\} Kaestner N, Syring EM. Follow-up of brief driver improvement interviews in Oregon. Traffic Safety Research Review 1968;12(4): 111-117.

\section{Kaestner 1983 \{published data only\}}

Kaestner N. Driver improvement schools - A second look. Oregon Motor Vehicles Division, Department of Transportation 1983.

\section{Kayser 1995 \{published data only\}}

Kayser RE, Schippers GM, Van Der Staak C. Evaluation of a Dutch educational 'Driving while intoxicated (DWI)' prevention program for driving schools. Journal of Drug Education 1995;25(4): 379-393.

Lynn 1982d \{published data only\}

* Lynn C. An evaluation of the impact of the Virginia driver improvement program on negligent driving: 12 month report. Virginia Department of Transportation Safety 1982; Vol. VHTRC 82-R43.

Lynn C. An evaluation of the impact of the Virginia driver improvement program on negligent driving: 24 month report. Virginia Department of Transportation Safety 1982; Vol. VHTRC 83-R6.

Lynn C. An evaluation of the the short-term effects of the Virginia driver improvement program: interim report. Virginia Department of Transportation Safety 1981; Vol. VHTRC 81-R46.

McKnight 1997 \{published data only\}

McKnight AJ, Tippetts AS. Accident prevention versus recidivism prevention courses for repeat traffic offenders. Accident Analysis \& Prevention 1997;29(1):25-31.

Mills 1996 \{published data only\}

Mills KL, Hall RD, Mcdonald M, Rolls GWP. The effects of hazard perception training on the development of novice driver skills.
Roadsafe '96: Influences affecting road user behaviour. 1996: $134-46$.

Mollenhauer 1997 \{published data only\}

Mollenhauer MA, Dingus TA, Carney C, Hankey JM, Jahns S. Anti-lock brake systems: an assessment of training on driver effectiveness. Accident Analysis and Prevention 1997;29(1):97-108.

Regan 1998a \{published data only\}

Regan M, Deery HA, Triggs TJ. Training for attentional control in novice car drivers: a simulator study. Proceedings of the Human Factor and Ergonomics Society 42nd annual meeting. 1998: 1452-56.

Regan 1998b \{published data only\} Regan MA, Deery HA, Triggs TJ. A technique for enhancing risk perception in novice car drivers. Road Safety Conference. Wellington, New Zealand, 16-17th November 1998; Vol. 1.

Schupack 1975 \{published data only\}

Schupack SA, Planek TW. An Evaluation of the National Safety Council's Defensive Driving Course as an adjunct to High School Driver Education Programs. Part 2. National Safety Council, Research Department, Chicago, IL, USA 1975.

Strang 1982 \{published data only\} Strang PM, Deutsch KB, James RS, Manders SM. A comparison of on-road and off-road driver training. Road Safety and Traffic Authority. Victoria, Australia.

Whittenburg 1974 \{published data only\} Whittenburg JA, McBride RS, Pain RF, Baker GL. Driver improvement training and evaluation. National Highway Traffic Safety Administration 1974; Vol. DOT-HS-133-1-200.

\section{References to studies awaiting assessment}

Ayers 1980 \{published data only\}

Ayers DJ. Evaluation of the behavior analysis driver interview. Olympia, WA: Research and Technology Division, Washington Department of Licensing 1980.

Bloch 1997 \{published data only\}

Bloch SA. The effectiveness of traffic violator schools: an examination of their effects on driver knowledge, attitudes, and performance. Automobile Club of Southern California, Los Angeles, CA 1997.

Brown 1975 \{published data only\}

Brown KB. Traffic court school coountermeasure. Sacramento Safety Council, Sacromento, CA 1975.

Bédard 2003 \{published data only\} Bédard M, Isherwood I, Moore E, Gibbons C, Lindstrom W. Evaluation of a re-training program for older drivers. Canadian Journal of Public Health 2003;95(4):295-8.

Eavy 1987 \{published data only\} Eavy PW, Edwards ML, Lee-Gosselin MH. Group interviews for probationary drivers with low violation levels: an evaluation of the traffic safety impact. Department of State, Lansing, MI 1987.

Epperson 1975 \{published data only\} Epperson WV, Harano RM. An evaluation of some additional factors influencing the effectiveness of warning letters. Accident Analysis \& Prevention 1975;7:239-47. 
Finigan 1995 \{published data only\}

Finigan M. Traffic violator school research report. Drivers.com 1995.

Harano 1974 \{published data only\}

Harano RM, Hubert DE. An evaluation of Californias "good driver" incentive program. Department of Motor Vehicles, Sacramento, CA 1974; Vol. Report no.46.

Jones 1987 \{published data only\}

Jones B. Oregon's habitual traffic offenders program: an evaluation of the effectiveness of license revocation. Journal of Safety Research 1987; 18 .

Jones 1993 \{published data only\}

Jones B. Effectiveness of the Oregon driver improvement program: 12-month report. Motor Vehicles Division, Salem, OR. 1993.

Jones 1997a \{published data only\}

Jones B. Age differences in response to high- and low-threat driver improvement. Journal of Safety Research 1997;28:15-28.

Jones 1997b \{published data only\}

Jones B. Age, gender, and the effectiveness of high threat letters: an analysis of Oregon's driver improvement advisory letters. Accident Analysis \& Prevention 1997;29:225-34.

Li 1976 \{published data only\}

Li LK, Waller PF. Evaluation of the North Carolina habitual offender law. Highway Safety Research Center, University of North Carolina, Chapel Hill, NC. 1976.

Marsh 1990 \{published data only\}

Marsh WC. Negligent-operator treatment evaluation system: program effectiveness report \#5. Department of Motor Vehicles, Sacramento CA. 1990;Report No. 128.

Marsh 1995 \{published data only\}

Marsh WC. Negligent-operator treatment evaluation system: program effectiveness report \#7. Department of Motor Vehicles, Sacramento CA 1995; Report No. 153

McBride 1970 \{published data only\}

McBride RS, Peck RC. Modifying negligent driving behavior through warning letters. Accident Analysis \& Prevention 1970;2 (141-74).

O'Brien 1981 \{published data only\}

O'Brien JP. Illinois Traffic Safety Programs: An evaluation of the Driver Improvement Program Conducted by Cook County (19771980). Illinois Department of Transport, Division of Traffic Safety 1981.

\section{O'Neall 1975 \{published data only\}}

O'Neall PA. An evaluation of two group interview and two lettercontact driver improvement programs. Department of Motor Vehicles, Olympia WA 1975; Vol. Report No. 37.

Owsley 2004 \{published data only\}

Owsley C, McGwin G, Phillips JM, McNeal SF, Stalvey BT. Impact of an educational program on the safety of high-risk, visually impaired, older drivers. American Journal of Preventive Medicine 2004;26(3):222-9.

Peck 1983 \{published data only\}

Peck RC, Kadell DJ. California's post-licensing control reporting and evaluation system - a summary of the first three years of results. Traffic Safety Evaluation Review 1983;2:7-22.

\section{PLCRES 1976-81 \{published data only\}}

Carpenter DW, Peck RC. Post licensing control reporting and evaluation system: negligent operator program effectiveness. California Department of Motor Vehicles 1980; Vol. Periodic status report \#6.

Kadell D, Howe W, Magistad J, Peck RC. Post licensing control reporting and evaluation system: negligent operator program effectiveness. California Department of Motor Vehicles 1976; Vol. Periodic status report \#1.

Kadell D, Peck R, Howe W, Epperson W. Post licensing control reporting and evaluation system: negligent operator program effectiveness. California Department of Motor Vehicles 1977; Vol. Periodic status report \#2.

Kadell D, Peck RC. Post licensing control reporting and evaluation system: negligent operator program effectiveness. California Department of Motor Vehicles 1979; Vol. Periodic status report \#4. Kadell D, Peck RC, Fong S, Marsh WC. Post licensing control reporting and evaluation system: negligent operator program effectiveness. California Department of Motor Vehicles 1980; Vol. Periodic status report \#5.

Kadell D, Peck RC, Howe W. Post licensing control reporting and evaluation system: negligent operator program effectiveness. California Department of Motor Vehicles 1978; Vol. Periodic status report \#3.

Wootton P, Carpenter DW, Peck RC. Post licensing control reporting and evaluation system: negligent operator program effectiveness. California Department of Motor Vehicles 1981; Vol. Periodic status report \#7 (summary).

Salzberg 1977 \{published data only\}

Salzberg PM, Klingberg CL. A supplemental evaluation of the defensive driving course as a rehabilitative component in the special adjudication for enforcement (SAFE) program. Department of Licensing, Olympia, WA 1977.

Salzberg 1978 \{published data only\} Salzberg PM, Klingberg CL. Rehabilitation effectiveness for safe project drivers receiving defensive driver course training. A supplemental evaluation report to NHTSA HS-804-777. Washington, DC: US Department of Transportation, National Highway Traffic Safety Administration 1978.

Salzberg 1979 \{published data only\} Salzberg PM, Paulsrude SP, McMurray L. An evaluation of the narrative driving interview program. Department of Licensing, Olympia WA 1979.

Salzberg 1985 \{published data only\} Salzberg PM, Ryser MR, Nuse RH, Paulsrude SP. Effectiveness of the goal setting program: an intervention for high-risk drivers. Department of Licensing, Olympia, WA 1985; Vol. Report No. 52.

Ulmer 1979 \{published data only\}

Ulmer RG, Jacobs HH. New Hampshire alcohol safety action project: Analysis of the effectiveness of driver retraining schools. US Department of Transportation. NHTSA, Washington, D.C 1979; Vol. DOT HS 055-1-071.

\section{Additional references}




\section{Berlin 1997}

Berlin JA. Does blinding of readers affect the results of MetaAnalyses?. Lancet 1997;350:185-6.

\section{DETR 2000}

Department of the Environment, Transport, the Regions.

Tomorrow's roads: safer for everyone. DETR 2000

\section{Dickersin 1994}

Dickersin K, Scherer R, Lefebvre C. Systematic reviews: Identifying relevant studies for systematic reviews. BMJ 1994;304:1286-91.

\section{HSE 2002}

Health \& Safety Executive. How safe are the railways?. www.hse.gov.uk/railways/howsafe.htm 2002.

\section{Mackay 2001}

Mackay M, Tiwari G. Prevention of Road Traffic Crashes. WHO meeting to Develop a 5 year Strategy for Road Traffic Injury Prevention. WHO, Geneva, C.H. April 2001:24-31.

\section{McCullagh 1989}

McCullagh P, Nelder JA. Generalised Linear Models, 2nd Ed. London: Chapman \& Hall, 1989

\section{Murray 1996}

Murray CJL, Lopez AD. Global health statistics: a compendium of incidence, prevalence and mortality estimates for over 200 conditions. Harvard School of Public Health, Boston: Harvard University Press, 1996.

\section{Roberts 2002}

Roberts I, Mohan D, Abbasi K. War on the roads. BMJ 2002;324: 1107-1108.

\section{Schulz 1995}

Schulz KF, Chalmers I, Hayes RJ, Altman DG. Empirical evidence of bias. Dimensions of methodological quality associated with estimates of treatment effects in controlled trials. JAMA 1995;273 (5):408-412.

* Indicates the major publication for the study 


\section{CHARACTERISTICS OF STUDIES}

\section{Characteristics of included studies [ordered by study ID]}

\section{Coppin 1962}

\begin{tabular}{l|l}
\hline Methods & $\begin{array}{l}\text { Allocation concealment: The method of allocation was not reported. } \\
\text { Loss to follow-up: Not reported. } \\
\text { Blinding of outcome assessment: Unclear from the trial report. }\end{array}$ \\
\hline Participants & $\begin{array}{l}\text { Remedial driver education: } \\
\text { Drivers who were eligible for 'driver improvement effort' in California, during December 1958 and March } \\
1959 \text { (n= 440). }\end{array}$ \\
\hline Interventions & $\begin{array}{l}\text { Drivers were divided into two groups. } \\
\text { Intervention: Group driver improvement meeting, lasting one hour. The aim was to 'sell' the need for } \\
\text { good driving habits and involved discussion of the general factors leading to poor driving (n=244). } \\
\text { Control: This group received no form of driver education (n=196). }\end{array}$ \\
\hline Outcomes & $\begin{array}{l}\text { After } 24 \text { months, the number of participants who had been involved in a crash, plus the total number of } \\
\text { crashes and traffic offences for each group. }\end{array}$ \\
\hline Notes & $\begin{array}{l}\text { Of the originally assigned drivers, those who did not attend the group meeting (approximately one in } \\
\text { three) were not included in the analysis. The participant numbers refer to the number of those who had } \\
\text { their records analysed. }\end{array}$ \\
\hline Item & $\begin{array}{l}\text { Allocation concealment? } \\
\text { Unclear }\end{array}$ \\
\hline
\end{tabular}

\section{Coppin 1965}

\begin{tabular}{ll} 
Methods & $\begin{array}{l}\text { Allocation concealment: The method of allocation was not reported. } \\
\text { Loss to follow-up: Not reported. } \\
\text { Blinding of outcome assessment: Adequate. }\end{array}$ \\
\hline Participants & $\begin{array}{l}\text { Remedial driver education: } \\
\text { Drivers who had accumulated four 'negligent operator points' in the } 12 \text { months prior to } 1962 \text { and had not } \\
\text { been previously contacted by the DMV as part of the negligent operator control programme. Participants } \\
\text { resided in the Californian metropolitan areas of either Fresno, Los Angeles, Oakland or Sacramento (n= } \\
2050) .\end{array}$ \\
\hline Interventions & $\begin{array}{l}\text { Drivers were divided into two groups. } \\
\text { Intervention: Group driver improvement meeting, the aim of which was to 'sell' safe driving }(\mathrm{n}=1440) . \\
\text { Control: This group was not contacted in any way }(\mathrm{n}=610) .\end{array}$
\end{tabular}




\section{Coppin 1965 (Continued)}

\begin{tabular}{ll} 
Outcomes & $\begin{array}{l}\text { After } 12 \text { months the number of participants who were involved in a crash or committed a traffic offence, } \\
\text { in each group. } \\
\text { The outcome data were obtained from the participants' main DMV files. }\end{array}$ \\
\hline Notes & $\begin{array}{l}\text { The records of drivers who were assigned to, but did not attend the group meeting, remained in the } \\
\text { analysis. }\end{array}$
\end{tabular}

\section{Risk of bias}

\begin{tabular}{l|ll}
\hline Item & Authors' judgement & Description \\
\hline Allocation concealment? & Unclear & B - Unclear \\
\hline
\end{tabular}

\section{Fuchs 1980}

\begin{tabular}{|c|c|c|}
\hline Methods & \multicolumn{2}{|c|}{$\begin{array}{l}\text { Allocation concealment: The control group was created by 'randomly selecting ten percent of the eligible } \\
\text { target group', as defined by every tenth name from the list of eligible drivers. } \\
\text { Loss to follow-up: This was not reported. } \\
\text { Blinding of outcome assessment: Unclear from the report. }\end{array}$} \\
\hline Participants & \multicolumn{2}{|c|}{$\begin{array}{l}\text { Remedial driver education: } \\
\text { Wisconsin state drivers who had accumulated } 7 \text { to } 11 \text { points in a } 12 \text { month period or were about to have } \\
\text { their licences reinstated following revocation or suspension }(n=95,068) \text {. } \\
\text { The assignment of drivers to the control group was conditional on them having no previous TSS experience. } \\
\text { However, no such constraint was imposed on those receiving treatment. }\end{array}$} \\
\hline Interventions & \multicolumn{2}{|c|}{$\begin{array}{l}\text { Drivers were divided into two groups. } \\
\text { Intervention: Driver education on an individual basis in the form of the counselling segment of the } \\
\text { Wisconsin Driver Improvement Programme }(n=84,300) \text {. } \\
\text { Control: This group was not notified for counselling }(n=10,768) \text {. }\end{array}$} \\
\hline Outcomes & \multicolumn{2}{|c|}{$\begin{array}{l}\text { After } 12 \text { months, the number of participants who were involved in a crash or committed a traffic offence, } \\
\text { in each group. }\end{array}$} \\
\hline \multicolumn{3}{|l|}{ Notes } \\
\hline \multicolumn{3}{|l|}{ Risk of bias } \\
\hline Item & Authors' judgement & Description \\
\hline Allocation concealment? & No & C - Inadequate \\
\hline
\end{tabular}


Harano 1972

\begin{tabular}{|c|c|c|}
\hline Methods & \multicolumn{2}{|c|}{$\begin{array}{l}\text { Allocation concealment: Allocation was carried out by a traffic court judge on an odd-even basis as defined } \\
\text { by the last digit of each participants' driving licence number. } \\
\text { Loss to follow-up: Not reported. } \\
\text { Blinding of outcome assessment: Adequate. }\end{array}$} \\
\hline Participants & \multicolumn{2}{|c|}{$\begin{array}{l}\text { Remedial driver education: } \\
\text { Drivers who had appeared in traffic court as a result of a recent traffic offence, from the areas of either } \\
\text { Richmond, Stockton, San Diego or Los Angeles in California. Participants were } 17 \text { to } 50 \text { years of age, } \\
\text { had held a Californian driving licence for a minimum of one year and had at least one prior traffic offence } \\
(\mathrm{n}=3544) \text {. }\end{array}$} \\
\hline Interventions & \multicolumn{2}{|c|}{$\begin{array}{l}\text { Drivers were divided into two groups. } \\
\text { Intervention: Group meeting following the UDIS curriculum, which had an emphasis on discussion }(\mathrm{n}= \\
\text { 1776). } \\
\text { Control: This group did not undergo any driver education, however, did receive the regular court dispo- } \\
\text { sition (usually a fine) ( } \mathrm{n}=1768) \text {. }\end{array}$} \\
\hline Outcomes & \multicolumn{2}{|c|}{ After 12 months, crashes and traffic offences as appearing on file at the DMV. } \\
\hline Notes & \multicolumn{2}{|c|}{$\begin{array}{l}\text { Raw crash and traffic offence data was not presented in the report. } \\
\text { There was evidence that individual traffic judges exercised selectivity during assignment and were more } \\
\text { reluctant to assign drivers with the poorer prior driving record, to the control group. }\end{array}$} \\
\hline \multicolumn{3}{|l|}{ Risk of bias } \\
\hline Item & Authors' judgement & Description \\
\hline Allocation concealment? & Unclear & B - Unclear \\
\hline
\end{tabular}

\section{Helander 1984a}

\begin{tabular}{ll} 
Methods & $\begin{array}{l}\text { Allocation concealment: Driver record printouts were sequentially allocated into baskets, each representing } \\
\text { a treatment condition. } \\
\text { Loss to follow-up: Not reported. } \\
\text { Blinding of outcome assessment: Unclear. }\end{array}$ \\
\hline Participants & $\begin{array}{l}\text { Remedial driver education: } \\
\text { Californian drivers who had been involved in a fatal crash or involved in three crashes within a } 12 \text { month } \\
\text { period ( } \mathrm{n}=6867) . \text { Drivers were not selected if they were eligible for any mandatory action or negligent } \\
\text { operator treatment of a higher priority. }\end{array}$ \\
\hline $\begin{array}{l}\text { Drivers were divided into four groups. } \\
\text { Intervention groups: } \\
\text { Individual education in the form of a one-on-one accident avoidance session, consisting of discussion and } \\
\text { orientated towards behaviour modification ( } \mathrm{n}=1712) . \\
\text { Correspondence education via mailed pamphlet and self-administered test }(\mathrm{n}=1709) . \\
\text { Re-examination group received the standard departmental intervention }(\mathrm{n}=1734) \text {. This intervention group } \\
\text { was not included in the analysis within this systematic review. }\end{array}$
\end{tabular}


Helander 1984a (Continued)

Control: This group was not contacted by the DMV ( $\mathrm{n}=1712)$.

\begin{tabular}{|c|c|c|}
\hline Outcomes & \multicolumn{2}{|c|}{ After 12 months, the mean number if crashes and traffic offences per participant, in each group. } \\
\hline Notes & \multicolumn{2}{|c|}{$\begin{array}{l}\text { This trial was reported within the same article as Helander } 1984 \mathrm{~b} \text {. All drivers assigned for treatment were } \\
\text { included in the trial's analysis, regardless of whether they actually received the treatment. }\end{array}$} \\
\hline \multicolumn{3}{|l|}{ Risk of bias } \\
\hline Item & Authors' judgement & Description \\
\hline Allocation concealment? & Unclear & B - Unclear \\
\hline
\end{tabular}

Helander 1984b

\begin{tabular}{|c|c|c|}
\hline Methods & \multicolumn{2}{|c|}{$\begin{array}{l}\text { Allocation concealment: Driver record printouts were sequentially allocation into baskets each representing } \\
\text { a treatment condition } \\
\text { Loss to follow-up: Not reported. } \\
\text { Blinding of outcome assessment: Unclear. }\end{array}$} \\
\hline Participants & \multicolumn{2}{|c|}{$\begin{array}{l}\text { Remedial driver education. } \\
\text { Californian drivers who had been involved in a fatal or injury crash plus another recorded crash in addition } \\
\text { to either } 2-3 \text { negligent operator points in one year, } 2-5 \text { in two years or } 3-6 \text { in three years }(n=24,156) \text {. } \\
\text { Drivers were not selected if they were eligible for any mandatory action or negligent operator treatment } \\
\text { of a higher priority. }\end{array}$} \\
\hline Interventions & \multicolumn{2}{|c|}{$\begin{array}{l}\text { Drivers were divided into three groups. } \\
\text { Interventions groups: } \\
\text { Individual education in the form of a one-on-one accident avoidance session orientated towards behaviour } \\
\text { modification ( } \mathrm{n}=8043) \text {. } \\
\text { Correspondence education via a mailed pamphlet and self-administered test }(\mathrm{n}=8061) \\
\text { Control: This group was not contacted by the DMV }(\mathrm{n}=8052) \text {. }\end{array}$} \\
\hline Outcomes & \multicolumn{2}{|c|}{ After 12 months, the mean number if crashes and traffic offences per participant, in each group. } \\
\hline Notes & \multicolumn{2}{|c|}{$\begin{array}{l}\text { This trial was reported within the same article as Helander } 1984 \mathrm{a} \text {. } \\
\text { All drivers assigned for treatment were included in the trial's analysis, regardless of whether they actually } \\
\text { received the treatment. }\end{array}$} \\
\hline \multicolumn{3}{|l|}{ Risk of bias } \\
\hline Item & Authors' judgement & Description \\
\hline Allocation concealment? & Unclear & B - Unclear \\
\hline
\end{tabular}


Kadell 1987a

\begin{tabular}{l|l} 
Methods & $\begin{array}{l}\text { Allocation concealment: Driver record printouts were sequentially allocated into baskets by the DDSL } \\
\text { scheduling unit. } \\
\text { Loss to follow-up: Not reported. } \\
\text { Blinding of outcome assessment: Adequate. }\end{array}$ \\
\hline Participants & $\begin{array}{l}\text { Remedial driver education. } \\
\text { Drivers with a 'point count at the negligent operator level' that is equal to or greater than four points } \\
\text { in } 12 \text { months, six points in } 24 \text { months or eight point in } 36 \text { months. Drivers had not received any other } \\
\text { negligent operator countermeasures, with the exception of a warning letter, nor did they qualify for a } \\
\text { countermeasure of higher priority }(\mathrm{n}=-19,600) .\end{array}$
\end{tabular}

Interventions
Intervention groups:
Group education meeting of approximately 1.5 hours covering a variety of safety topics through presen-
tations, film, tests and discussion $(\mathrm{n}=-4900)$.
$\begin{aligned} & \text { A second group also received group education meeting, however, this session emphasised the } 55 \mathrm{MSL} \text { law } \\ & (\mathrm{n}=-4900) .\end{aligned}$
$\begin{aligned} & \text { Correspondence education group received HI/PRI; a package mailed to the driver containing instructional } \\ & \text { materials such as information sheets and a manual. These drivers were offered conviction masking as an } \\ & \text { incentive for programme compliance }(\mathrm{n}=4900) . \\ & \text { Control: This group was not contacted }(\mathrm{n}=4900) .\end{aligned}$

Outcomes After 12 months, the number if participants who were involved in a crash, in an injury crash or committed a traffic offence, in each group. The outcome data were obtained from DMV files.

Notes This trial was reported within the same article as Kadell 1984b.

All drivers remained in the analysis regardless of whether they actually received their allocation treatment.

Risk of bias

\begin{tabular}{|c|c|c|}
\hline Item & Authors' judgement & Description \\
\hline Allocation concealment? & No & $\mathrm{C}$ - Inadequate \\
\hline
\end{tabular}

Kadell 1987b

\begin{tabular}{l|l} 
Methods & $\begin{array}{l}\text { Allocation concealment: Allocation was based on the last two digits of the participants driver licence } \\
\text { number. } \\
\text { Loss to follow-up: Not reported. } \\
\text { Blinding of outcome assessment: Adequate. }\end{array}$ \\
\hline Participants & $\begin{array}{l}\text { Remedial driver education. } \\
\text { Californian drivers selected on the basis of the number of } 55 \text { MSL offences. Individuals were eligible if } \\
\text { their last offence was a } 55 \text { MSL offence and another } 55 \text { MSL offence had occurred in the prior } 12 \text { months } \\
(\mathrm{n}=-24,000) \text {. Eligible drivers had no known history of undergoing other driver remediation and did not } \\
\text { simultaneously qualify for another DMV remediation programme. }\end{array}$
\end{tabular}


Kadell 1987b (Continued)

\begin{tabular}{|c|c|c|}
\hline Interventions & \multicolumn{2}{|c|}{$\begin{array}{l}\text { Drivers were divided into two groups. } \\
\text { Intervention: } \\
\text { Correspondence education in the form of speed HI/PRI, a package mailed to the driver containing } \\
\text { instructional materials such as information sheets and a manual, with the focus on the } 55 \text { MSL law. These } \\
\text { drivers were offered conviction masking as an incentive for programme compliance }(n=-12,000) \text {. } \\
\text { Control: This group was not contacted }(n=-12,000) \text {. }\end{array}$} \\
\hline Outcomes & \multicolumn{2}{|c|}{$\begin{array}{l}\text { After } 12 \text { months, the number of participants who were involved in a crash, injury crash or committed a } \\
\text { traffic offence, in each group. } \\
\text { The outcome data were obtained from DMV files. }\end{array}$} \\
\hline Notes & \multicolumn{2}{|c|}{$\begin{array}{l}\text { This trial was reported within the same article as Kadell } 1984 \mathrm{a} \text {. } \\
\text { All drivers remained in the analysis regardless of whether they actually received their allocated treatment. }\end{array}$} \\
\hline \multicolumn{3}{|l|}{ Risk of bias } \\
\hline Item & Authors' judgement & Description \\
\hline Allocation concealment? & No & $\mathrm{C}$ - Inadequate \\
\hline
\end{tabular}

Kaestner 1967

\begin{tabular}{l|l} 
Methods & $\begin{array}{l}\text { Allocation concealment: Participants were assigned on an odd/even basis, no further details were reported. } \\
\text { Loss to follow-up: Approximately nine per cent of participants. } \\
\text { Blinding of outcome assessment: Unclear. }\end{array}$ \\
\hline Participants & $\begin{array}{l}\text { Remedial driver education. } \\
\text { Male drivers between the ages of } 16 \text { and } 64 \text { years, resident in Oregon, who had accumulated two or more } \\
\text { entries for traffic offences, on their licence in the prior nine months and had received only one previous } \\
\text { advisory letter }(\mathrm{n}=1320) . \text { Drivers with entries for drink driving or several reckless driving charges were } \\
\text { not eligible. }\end{array}$ \\
\hline
\end{tabular}

\begin{tabular}{l|l} 
Interventions & $\begin{array}{l}\text { Drivers were divided into two groups. } \\
\text { Intervention: } \\
\text { Individual driver improvement interview that was educationally and motivationally orientated involving } \\
\text { a review of the traffic laws and an 'involvement enquiry' specific to the drivers' previous violations (n= } \\
660) . \\
\text { Control: This group did not receive the interview. }\end{array}$ \\
\hline Outcomes & $\begin{array}{l}\text { After } 12 \text { months, the number of 'successes' ( no entry for a crash or traffic offence) and 'failures' (at least } \\
\text { one entry for a crash or traffic offence) were records for both groups. The number of drivers committing } \\
\text { a moving traffic offence and drivers involved in an avoidable crash were distinguished within the 'failures' } \\
\text { data. }\end{array}$ \\
\hline
\end{tabular}

Twenty-four months outcome data were reported in Kaestner 1968, however, this second year sample only consisted of drivers who drive the first year without a recorded traffic incident. 
Kaestner 1967 (Continued)

\section{Risk of bias}

\begin{tabular}{l|ll}
\hline Item & Authors' judgement & Description \\
\hline Allocation concealment? & No & C - Inadequate \\
\hline
\end{tabular}

\section{Kaestner 1975}

Methods

Allocation concealment: The method of allocation was not reported.

Loss to follow-up: Approximately 3 per cent of participants.

Blinding of outcome assessment: Unclear.

Pemedial driver education.
Oregon drivers who were eligible for suspension of their driving privileges; one conviction for a moving
traffic offence in six months or two in 12 months following an interview $(\mathrm{n}=960)$.
traffic offence in six months or two in 12 months following an interview ( $\mathrm{n}=960)$.

\begin{tabular}{ll} 
Interventions & $\begin{array}{l}\text { Drivers were divided into five groups. } \\
\text { Intervention groups: } \\
\text { Group education meeting in the form of NSC's DDC. This course was only available in the cities of } \\
\text { Portland, Salem and Eugene in Oregon ( } \mathrm{n}=97) . \\
\text { Correspondence education group received a last chance warning letter and a manual ( } \mathrm{n}=206) . \\
\text { A third group received a probationary (restrictive) licence for one month, which allowed participants to } \\
\text { drive to and from school or work ( } \mathrm{n}=222) \text {. This intervention was not included in the analysis within this } \\
\text { systematic review. } \\
\text { A fourth group received the 'usual } 30 \text { day driver improvement suspension' (n=208). This intervention } \\
\text { was not included in the analysis within this systematic review. } \\
\text { Control: Participants in this group were not contacted (n=199). }\end{array}$ \\
\hline Outcomes & $\begin{array}{l}\text { After } 12 \text { months the percentage of drivers considered to be 'successes' (no entry for a crash or traffic } \\
\text { offence) was recorded for each group. }\end{array}$ \\
\hline Notes & $\begin{array}{l}\text { Twenty-eight drivers were lost to follow-up as they were not resident in Oregon for the duration of the } \\
\text { study period. }\end{array}$ \\
\hline Risk of bias & Authors' judgement \\
\hline Item & Unclear \\
\hline Allocation concealment? & Description \\
\hline
\end{tabular}


Kaestner 1980

\begin{tabular}{ll}
\hline Methods & $\begin{array}{l}\text { Allocation concealment: Participants were assigned on the basis of the last two digits of their licence } \\
\text { number. } \\
\text { Loss to follow-up: Not reported. } \\
\text { Blinding of outcome assessment: Unclear. }\end{array}$ \\
\hline Participants & $\begin{array}{l}\text { Remedial driver education } \\
\text { Oregon drivers who were eligible for 'additional attention from the Oregon driver improvement pro- } \\
\text { gramme' between November } 1978 \text { and April 1979, no further information was reported (n=1377). }\end{array}$ \\
\hline Interventions & $\begin{array}{l}\text { Drivers were divided into three groups. } \\
\text { Intervention groups: } \\
\text { Group driver education in the form of NTSI one day, eight hour course with a focus on driver attitudes } \\
\text { and lawful driving, using a combination of discussion, video and questionnaires (n=469). } \\
\text { Group driver education in the form of the one day NSC's DDC with a focus on crash reduction, using a } \\
\text { combination of discussion, video and questionnaires (n=449). } \\
\text { Control: This group was not contacted (n=459). }\end{array}$ \\
\hline
\end{tabular}

Outcomes After 12 months, the number of 'successes' (drivers who had no moving traffic offences or chargeable crashes) and 'failures' (at least one entry for a moving traffic offence or chargeable crash), in each group.

Notes

Participants who received treatments other than that dictated by the original random allocation, were deleted from the study.

Drivers were included in the analysis even if they failed to complete the treatment.

\section{Risk of bias}

\begin{tabular}{l|ll}
\hline Item & Authors' judgement & Description \\
\hline Allocation concealment? & No & C - Inadequate \\
\hline
\end{tabular}

\section{Lynn 1982a}

\begin{tabular}{l|l} 
Methods & $\begin{array}{l}\text { Allocation concealment: Participants were assigned to groups based on the millisecond of entry on their } \\
\text { driver record, the traffic offence making them eligible for inclusion. No further details were reported. } \\
\text { Loss to follow-up: Not reported. } \\
\text { Blinding of outcome assessment: Unclear. }\end{array}$ \\
\hline Participants & $\begin{array}{l}\text { Remedial driver education } \\
\text { Drivers within the State of Virginia, who had accumulated either six points in one year or nine points in } \\
\text { a two year period (n=9783). }\end{array}$ \\
\hline Interventions & $\begin{array}{l}\text { Drivers were divided into two groups. } \\
\text { Intervention: Correspondence education in the form of an advisory letter }(\mathrm{n}=4899) . \\
\text { Control: This group did not receive an advisory letter }(\mathrm{n}=4884) .\end{array}$ \\
\hline
\end{tabular}

Outcomes

After 12 months the percentage of 'survivors' (those who did not incur subsequent traffic offences). 
Lynn 1982a (Continued)

\begin{tabular}{|c|c|c|}
\hline Notes & \multicolumn{2}{|c|}{$\begin{array}{l}\text { This trial was reported within the same article as Lynn b and c. } \\
\text { Analysis of variance and adjusted data were presented after } 24 \text { months, however, no raw data suitable for } \\
\text { this review was presented for this follow-up period. } \\
\text { Participants assignment was equally distributed over a } 12 \text { month period. }\end{array}$} \\
\hline \multicolumn{3}{|l|}{ Risk of bias } \\
\hline Item & Authors' judgement & Description \\
\hline Allocation concealment? & Unclear & B - Unclear \\
\hline
\end{tabular}

\section{Lynn 1982b}

Methods

Allocation concealment: Participants were assigned to groups based on the millisecond of entry on their driver record, the traffic offence making them eligible for inclusion. No further details were reported.

Loss to follow-up: Not reported.

Blinding of outcome assessment: Unclear.

Remedial driver education
Drivers within the State of Virginia, who had accumulated either eight points in one year or 12 points in
a two year period $(\mathrm{n}=9266)$.

\begin{tabular}{ll}
\hline Interventions & $\begin{array}{l}\text { Drivers were divided into two groups. } \\
\text { Intervention: } \\
\text { Group interview. No further details were reported ( } \mathrm{n}=4649) . \\
\text { Control: No educational intervention. No further details were reported ( } \mathrm{n}=4617) .\end{array}$ \\
\hline Outcomes & After 12 months the percentage of 'survivors' (those who did not incur subsequent traffic offences). \\
\hline Notes & $\begin{array}{l}\text { This trial was reported within the same article as Lynn a and c. } \\
\text { Analysis of variance and adjusted data were presented after } 24 \text { months, however, no raw data suitable for } \\
\text { this review was presented for this follow-up period. } \\
\text { Participants assignment was equally distributed over a } 12 \text { month period. }\end{array}$ \\
\hline
\end{tabular}

\section{Risk of bias}

\begin{tabular}{l|ll}
\hline Item & Authors' judgement & Description \\
\hline Allocation concealment? & Unclear & B - Unclear \\
\hline
\end{tabular}


Lynn 1982c

Methods Allocation concealment: Participants were assigned to groups based on the millisecond of entry on their driver record, the traffic offence making them eligible for inclusion. No further details were reported.

Loss to follow-up: Not reported.

Blinding of outcome assessment: Unclear.

Remedial driver education
Drivers within the State of Virginia, who had accumulated either eight points in one year or 12 points
in a two year period ( $\mathrm{n}=3388)$. Participants may have received an advisory letter and/or undergone the
group interview treatments previously.

Interventions $\quad$ Drivers were divided into two groups.

Intervention:

Personal interview. No further details were reported $(\mathrm{n}=1738)$.

Control: No further details were reported $(n=1650)$.

Outcomes

After 12 months the percentage of 'survivors' (those who did not incur subsequent traffic offences).

This trial was reported within the same article as Lynn a and b.
Analysis of variance and adjusted data were presented after 24 months, however, no raw data suitable for
this review was presented for this follow-up period.
Participants assignment was equally distributed over a 12 month period.

Risk of bias

\begin{tabular}{l|ll}
\hline Item & Authors' judgement & Description \\
\hline Allocation concealment? & Unclear & B - Unclear \\
\hline
\end{tabular}

Marsh 1971

\begin{tabular}{ll} 
Methods & $\begin{array}{l}\text { Allocation concealment: Participants were allocated to groups on the basis of the last two digits of their } \\
\text { licence number. } \\
\text { Loss to follow-up: Not reported. } \\
\text { Blinding of outcome assessment: Unclear. }\end{array}$ \\
\hline Participants & $\begin{array}{l}\text { Remedial driver education. } \\
\text { Californian drivers licence holders, resident in one of the project areas (Los Angeles, San Diego, Oakland, } \\
\text { Long Beach and Santa Ana) and between the ages of } 16 \text { and } 60 . \text { Eligible drivers also had no record of a } \\
\text { previous contact by DMV in relation to the negligent operator programme and had accumulated 3.5 to } \\
4.5 \text { selection points in the prior } 12 \text { months, including at least two traffic offences and no more than three } \\
\text { crashes }(\mathrm{n}=15,290) .\end{array}$ \\
\hline
\end{tabular}

Interventions

Drivers were divided into nine groups.

Five groups received education through forms of group meetings:

Subject Interaction Meeting in which the group leader acted to facilitate group discussion, with the aim of encouraging drivers to recognise the 'rationalisation used to defend poor driving' $(n=1810)$.

Leader Interaction Meeting in which the group facilitator took the lead in the discussion, attempting to involve each driver $(\mathrm{n}=1824)$. 
Marsh 1971 (Continued)

\begin{tabular}{|c|c|c|}
\hline & \multicolumn{2}{|c|}{$\begin{array}{l}\text { Group Educational Meeting which stressed defensive driving techniques and perception of driving hazards. } \\
\text { Group discussion was promoted ( } \mathrm{n}=1741 \text { ). } \\
\text { Driver Improvement Meeting in which a prepared script was followed with the aim of selling safe driving } \\
\text { and obeying laws ( } \mathrm{n}=1856 \text { ). } \\
\text { Group Administrative Review information in this group was delivered in a 'firm and straight-forward } \\
\text { warning' using a prepared script and group discussion was kept to a minimum ( } \mathrm{n}=1883 \text { ). } \\
\text { Each of these group treatments lasted } 1-1.5 \text { hours involving } 12 \text { or } 18 \text { drivers per session. } \\
\text { Two group received education delivered on an individual basis: } \\
\text { The Regular Individual Hearing group involved the DMV's standard treatment. Emphasis was placed on } \\
\text { the legal basis for driver control, stressing the importance of safe driving and the potential penalties for } \\
\text { further traffic offences. The atmosphere was kept informal throughout ( } \mathrm{n}=1607) \text {. } \\
\text { Experimental Individual Hearing used a 'here and now' approach, attempting to maximise personal } \\
\text { communication with the participant ( } \mathrm{n}=1567) \text {. } \\
\text { Control: Participants in this group were sent a letter inviting them to participate in a DMV survey, } \\
\text { however, no education was provided ( } \mathrm{n}=1530 \text { ). }\end{array}$} \\
\hline Outcomes & \multicolumn{2}{|c|}{ After 12 months, the number of crashes and traffic offences per 100 drivers, in each group. } \\
\hline Notes & \multicolumn{2}{|c|}{$\begin{array}{l}\text { A large number of participants assigned to the group meeting treatments did not attend ( }-50 \text { per cent) } \\
\text {, however the subsequent driving records of all the originally assigned driver were kept in the trial's data } \\
\text { analysis. }\end{array}$} \\
\hline \multicolumn{3}{|l|}{ Risk of bias } \\
\hline Item & Authors' judgement & Description \\
\hline Allocation concealment? & No & $\mathrm{C}$ - Inadequate \\
\hline
\end{tabular}

\section{Marsh 1978}

Methods

Allocation concealment: Participants were assigned to groups using a predetermined sequence that had been determined using a table of random numbers.

Loss to follow-up: 118 participants from the original 17,780 sample were lost to follow-up.

Blinding of outcome assessment: Adequate.

\begin{tabular}{ll} 
Participants & $\begin{array}{l}\text { Remedial driver education. } \\
\text { Californian drivers who were identified by computer as having accumulating three to five traffic offence } \\
\text { points in the prior } 12 \text { months ( } \mathrm{n}=17,780) \text {. The target group did not have a record of a previous GEM or } \\
\text { Negligent Operator hearing. }\end{array}$ \\
\hline Interventions & $\begin{array}{l}\text { Drivers were divided into seven groups. } \\
\text { Intervention groups } \\
\text { Group education: Four treatment groups involved three types of group education, three being modifica- } \\
\text { tions of the standard GEM: } \\
\text { Standard GEM that included a short safety film ( } \mathrm{n}=2539) . \\
\text { Training in Perceptual Strategy (TIPS) was a } 1.5 \text { hour session containing materials aimed at enhancing } \\
\text { negligent operators perceptual strategies }(\mathrm{n}=2538) . \\
\text { Combined Attitude and TIPS, was a three hour course with a similar content to TIPS with the addition }\end{array}$
\end{tabular}


Marsh 1978 (Continued)

\begin{tabular}{ll} 
of some attitudinally related subject matter (n=2538). & $\begin{array}{l}\text { Mandatory Control, the content of this course was identical to that of the Combined Attitude and TIPs, } \\
\text { with the exception that attendance was required under the threat of possible licence suspension (n=2535) } \\
\text { Correspondence education groups: } \\
\text { HI/PRI required participants to complete learning homework package, who were eligible for point re- } \\
\text { duction upon completion of the homework (n=2550). } \\
\text { Home instruction: This group received the same homework package as HI/PRI, however, participants } \\
\text { were not offered the point reduction incentive upon completion (n=2536). } \\
\text { Control: This group was not contacted (n=2539). }\end{array}$ \\
\hline Outcomes & $\begin{array}{l}\text { After } 12 \text { months, the crash and traffic offence means per driver, in each group. } \\
\text { Outcome data were obtained from DMV records. }\end{array}$ \\
\hline Notes & $\begin{array}{l}\text { Approximately one per cent of participants who were allocated to the control group mistakenly received } \\
\text { a treatment. However, drivers were analysed on an intention to treat basis. }\end{array}$ \\
\hline Risk of bias & \begin{tabular}{l} 
Authors' judgement \\
\hline Item
\end{tabular} \\
\hline Allocation concealment? & Unclear \\
\hline
\end{tabular}

\section{McCoy 1993}

Methods

Allocation concealment: The method of allocation was not reported.

Loss to follow-up:

Blinding of outcome assessment: Unclear.

Participants

Advanced driver education ('older drivers').

'Older' drivers between the ages of 65 and 88 from Nebraska, USA. Participants were required to be in good health, be a regular driver and have not taken an 'older' driver training course previously. Drivers were volunteers who were paid $\$ 25$ for their time $(n=105)$.

Interventions

Drivers were divided into six groups.

Intervention groups:

Group driver education based on the AAA Safe Driving for Mature Operators Programme, involving one full day of instruction $(\mathrm{n}=15)$.

The physical therapy treatment involved seven at-home exercises designed to improve posture, trunk rotation, neck and shoulder flexibility, to be done for eight weeks $(n=18)$. This intervention was not relevant for this systematic review.

The perceptual therapy treatment involved an eight week course of at-home exercises designed to improve visual perception in the form of spatial relationships, visual discrimination, figure-ground, visual closure and visual memory $(\mathrm{n}=10)$. This intervention was not relevant for this systematic review.

The physical therapy and driver education group underwent a combination of the AAA Safe Driving for Mature Operators Programme and physical therapy exercises $(n=15)$.

The perceptual therapy and driver education group underwent a combination of the AAA Safe Driving for Mature Operators Programme and perceptual therapy exercises $(n=19)$. 
McCoy 1993 (Continued)

Control: This group did not receive either therapies or driver education treatment $(n=17)$.

\begin{tabular}{|c|c|c|}
\hline Outcomes & \multicolumn{2}{|c|}{$\begin{array}{l}\text { Driving performance on a test route as measured by a driver performance measurement (DPM) devel- } \\
\text { oped at Michigan State University. Participants were tested before and other the countermeasures were } \\
\text { implemented. The change in DPM scores was used as the primary measure of effectiveness. }\end{array}$} \\
\hline Notes & \multicolumn{2}{|c|}{ Of the 105 drivers originally assigned, 11 dropped out of the study due to illness or other commitments. } \\
\hline \multicolumn{3}{|l|}{ Risk of bias } \\
\hline Item & Authors' judgement & Description \\
\hline Allocation concealment? & Unclear & B - Unclear \\
\hline
\end{tabular}

Nolen 2002

\begin{tabular}{|c|c|c|}
\hline Methods & \multicolumn{2}{|c|}{$\begin{array}{l}\text { Allocation concealment: Participants were allocated using a combination of drawing lots and alternation. } \\
\text { Loss to follow-up: Twenty-nine percent. } \\
\text { Blinding of outcome assessment: Adequate. }\end{array}$} \\
\hline Participants & \multicolumn{2}{|c|}{$\begin{array}{l}\text { Advanced driver education. } \\
\text { Swedish drivers between the ages of } 18 \text { and } 24 \text { who had insurance with the Swedish Insurance company, } \\
\text { Skandia. Drivers had responded to an invitation to participants in the course }(\mathrm{n}=2305) \text {. }\end{array}$} \\
\hline Interventions & \multicolumn{2}{|c|}{$\begin{array}{l}\text { Drivers were divided into two groups. } \\
\text { Intervention: } \\
\text { Group driver education of full and half day courses with the main focus on communicating insight } \\
\text { regarding the need for larger safety margins, using practical and theoretical exercises }(n=1502) \text {. } \\
\text { Control: } \\
\text { No education }(n=803) \text {. }\end{array}$} \\
\hline Outcomes & \multicolumn{2}{|c|}{$\begin{array}{l}\text { After } 24 \text { months, the number of traffic injuries, in both groups according to data obtained from sever } \\
\text { insurance companies in Sweden. }\end{array}$} \\
\hline \multicolumn{3}{|l|}{ Notes } \\
\hline \multicolumn{3}{|l|}{ Risk of bias } \\
\hline Item & Authors' judgement & Description \\
\hline Allocation concealment? & Unclear & B - Unclear \\
\hline
\end{tabular}


Peck 1980

\begin{tabular}{|c|c|c|}
\hline Methods & \multicolumn{2}{|c|}{$\begin{array}{l}\text { Allocation concealment: Participants were allocated to groups on the basis of the terminal digit of their } \\
\text { driving licence number. } \\
\text { Loss to follow-up: Not reported. } \\
\text { Blinding of outcome assessment: Adequate. }\end{array}$} \\
\hline Participants & \multicolumn{2}{|c|}{$\begin{array}{l}\text { Remedial driver education. } \\
\text { Drivers who had been convicted of a non-alcohol related traffic offence selected from co-operating courts, } \\
\text { between August and November } 1977(n=14,278) \text {. }\end{array}$} \\
\hline Interventions & \multicolumn{2}{|c|}{$\begin{array}{l}\text { Drivers were divided into two groups. } \\
\text { Intervention: } \\
\text { Group education in the form of Traffic Violator School ( } n=9318) \text {. } \\
\text { Control: This group was required to pay the normal school tuition fees but were dismissed }(n=4960) \text {. }\end{array}$} \\
\hline Outcomes & \multicolumn{2}{|c|}{$\begin{array}{l}\text { After six months mean number of crashes and traffic offences in each group. } \\
\text { The outcome data was obtained from the DMV's central computer records. }\end{array}$} \\
\hline Notes & \multicolumn{2}{|c|}{$\begin{array}{l}\text { Thirty-two per cent of drivers who should have been in the control group were incorrectly assigned to the } \\
\text { treatment group. }\end{array}$} \\
\hline \multicolumn{3}{|l|}{ Risk of bias } \\
\hline Item & Authors' judgement & Description \\
\hline Allocation concealment? & No & C - Inadequate \\
\hline
\end{tabular}

\section{Prothero 1978}

\begin{tabular}{|c|c|}
\hline Methods & $\begin{array}{l}\text { Allocation concealment: Participants were randomly allocated by a court hearing officer, no further infor- } \\
\text { mation was reported. } \\
\text { Loss to follow-up: Seven participants were lost to follow-up. } \\
\text { Blinding of outcome assessment: Unclear. }\end{array}$ \\
\hline Participants & $\begin{array}{l}\text { Remedial driver education. } \\
\text { Drivers resident in Florida who had lost or were about to lose their drivers licence for } 30 \text { days or more } \\
\text { and were attempting to obtain, through a court hearing, a restrictive driving privilege, between November } \\
1974 \text { and April } 1975(\mathrm{n}=432) \text {. }\end{array}$ \\
\hline Interventions & $\begin{array}{l}\text { Drivers were divided into three groups. } \\
\text { Intervention groups: } \\
\text { Group driver education: } \\
\text { NSC's DDC consisting of an eight-hour lecture course on advanced driving knowledge }(n=109) \text {. } \\
\text { Experimental course was an eight-hour lecture-discussion that focused on how to change problem driving } \\
\text { behaviour ( } n=137) \text {. } \\
\text { Control: This group received no educational intervention, instead they were given a date to return to the } \\
\text { office of the hearing officer when they would take two post-tests }(n=112) \text {. }\end{array}$ \\
\hline
\end{tabular}


Prothero 1978 (Continued)

\begin{tabular}{|c|c|c|}
\hline Outcomes & \multicolumn{2}{|c|}{$\begin{array}{l}\text { After } 12 \text { months, the mean number of crashes and traffic offences were recorded for each group, as well } \\
\text { as the improvement in knowledge measured by pre and post tests. }\end{array}$} \\
\hline Notes & \multicolumn{2}{|c|}{$\begin{array}{l}\text { A total of } 432 \text { drivers were originally assigned to groups, however, only the driving records of } 358 \text { of } \\
\text { them were analysed in the report. The remaining } 74 \text { drivers were either lost to follow-up, or had failed to } \\
\text { complete their allocated treatment. }\end{array}$} \\
\hline \multicolumn{3}{|l|}{ Risk of bias } \\
\hline Item & Authors' judgement & Description \\
\hline Allocation concealment? & No & C - Inadequate \\
\hline
\end{tabular}

\section{Ratz 1978}

\begin{tabular}{|c|c|c|}
\hline Methods & \multicolumn{2}{|c|}{$\begin{array}{l}\text { Allocation concealment: Participants were allocated to groups on the basis of the terminal digit of their } \\
\text { driving licence number. } \\
\text { Loss to follow-up: Not reported. } \\
\text { Blinding of outcome assessment: Adequate. }\end{array}$} \\
\hline Participants & \multicolumn{2}{|c|}{$\begin{array}{l}\text { Remedial driver education. } \\
\text { Californian drivers who were applying to renew their drivers licence, who had a prior three year driving } \\
\text { record involving at least two crashes or one crash plus three traffic offences, or more than four traffic } \\
\text { offences }(n=18,749) \text {. }\end{array}$} \\
\hline Interventions & \multicolumn{2}{|c|}{$\begin{array}{l}\text { Drivers were divided into three groups. } \\
\text { Intervention groups: } \\
\text { Group education in the form of a traffic safety film, emphasising defensive driving, accompanied by a test } \\
\text { of visual acuity and written test ( } \mathrm{n}=6270) \text {. } \\
\text { Individual education in the form of a diagnostic test with counselling, the aim of which was to identify } \\
\text { and discuss the driver's shortcoming in driving habits }(\mathrm{n}=6116) \text {. } \\
\text { Control: This group received the standard renewal procedure involving a visual acuity and written test } \\
(\mathrm{n}=6363) \text {. }\end{array}$} \\
\hline Outcomes & \multicolumn{2}{|c|}{ After 12 months, the number of crashes, injury crashes and traffic offences per 1000 drivers, in each group } \\
\hline Notes & \multicolumn{2}{|c|}{ Participants who failed to complete the intervention were kept in their respective groups for the analysis. } \\
\hline \multicolumn{3}{|l|}{ Risk of bias } \\
\hline Item & Authors' judgement & Description \\
\hline Allocation concealment? & No & C - Inadequate \\
\hline
\end{tabular}




\begin{tabular}{|c|c|c|}
\hline Methods & \multicolumn{2}{|c|}{$\begin{array}{l}\text { Allocation concealment: Participants were allocated by clerks in the Traffic Court who placed requests } \\
\text { alternately into two bins, each representing a treatment condition. } \\
\text { Loss to follow-up: Not reported. } \\
\text { Blinding of outcome assessment: Adequate. }\end{array}$} \\
\hline Participants & \multicolumn{2}{|c|}{$\begin{array}{l}\text { Remedial driver education. } \\
\text { Illinois drivers who had committed their first driving offence. The drivers pleaded guilty and requested } \\
\text { TSS in lieu of a trial. Participants were resident in Chicago and had no record of receiving DDC previously } \\
(\mathrm{n}=940) \text {. }\end{array}$} \\
\hline Interventions & \multicolumn{2}{|c|}{$\begin{array}{l}\text { Drivers were divided into two groups. } \\
\text { Intervention } \\
\text { Group driver education: This group attended TSS and received a four hour course based on the NSC's } \\
\text { DDC ( } \mathrm{n}=452) \text {. } \\
\text { Control: This group received a letter informing them that due to scheduling difficulties, they could not } \\
\text { attend TSS as requested }(\mathrm{n}=488) \text {. }\end{array}$} \\
\hline Outcomes & \multicolumn{2}{|c|}{$\begin{array}{l}\text { After } 12 \text { months, the number of 'stops' for traffic offences and the mean number of tickets per driver, were } \\
\text { recorded for participants in each group. } \\
\text { Outcome data was obtained from the Cook County traffic-offence database. }\end{array}$} \\
\hline \multicolumn{3}{|l|}{ Notes } \\
\hline \multicolumn{3}{|l|}{ Risk of bias } \\
\hline Item & Authors' judgement & Description \\
\hline Allocation concealment? & Yes & A - Adequate \\
\hline
\end{tabular}

\section{Schuman 1971}

\begin{tabular}{l|l} 
Methods & $\begin{array}{l}\text { Allocation concealment: Participants were 'randomly selected' from the target population, further details } \\
\text { were not reported. } \\
\text { Loss to follow-up: Not reported. } \\
\text { Blinding of outcome assessment: Adequate. }\end{array}$ \\
\hline Participants & $\begin{array}{l}\text { Advanced driver education ('young' drivers) } \\
\text { Participants were 'senior' students from a Michigan High School, aged } 18 \text { to } 20 \text { years, all of whom had } \\
\text { completed a questionnaire concerning road experience ( } \mathrm{n}=133) .\end{array}$ \\
\hline Interventions & $\begin{array}{l}\text { Drivers were divided into two groups. } \\
\text { Intervention: } \\
\text { Group driver education: This group attend a series of seven two-hour sessions or workshops over seven } \\
\text { weeks. The course was a 'booster' programme with the aim of building on driver education and acceler- } \\
\text { ating the natural process of driving development, that provided a open, informal setting for discussion. } \\
\text { Personalised letters were sent to participants six and } 12 \text { months after completion of the course (n=19). } \\
\text { Control: This group received no form of driver education ( } \mathrm{n}=114) .\end{array}$
\end{tabular}


Schuman 1971 (Continued)

\begin{tabular}{|c|c|c|}
\hline Outcomes & \multicolumn{2}{|c|}{$\begin{array}{l}\text { After } 24 \text { months, the number of drivers involved in one or more crashes was recorded for each group. } \\
\text { This crash data was obtained from official Michigan state files. }\end{array}$} \\
\hline Notes & & \\
\hline \multicolumn{3}{|l|}{ Risk of bias } \\
\hline Item & Authors' judgement & Description \\
\hline Allocation concealment? & Unclear & B - Unclear \\
\hline
\end{tabular}

\section{Stoke 1980}

\begin{tabular}{ll} 
Methods & $\begin{array}{l}\text { Allocation concealment: From a list of eligible drivers, every nth individual was selected and systematically } \\
\text { allocated to one of four groups. No further details were reported. } \\
\text { Loss to follow-up: Not reported } \\
\text { Blinding of outcome assessment: Adequate. }\end{array}$ \\
\hline Participants & $\begin{array}{l}\text { Advanced driver education. } \\
\text { Virginia state drivers, who had applied to renew their driving licence. Drivers who had to pass a written } \\
\text { knowledge test because they had a crash and/or traffic offence of a defined criteria, and those who had the } \\
\text { licence revoked for DUI were not included ( } \mathrm{n}=47,628) .\end{array}$ \\
\hline Interventions & $\begin{array}{l}\text { Drivers were divided into four groups. } \\
\text { Intervention groups: } \\
\text { Correspondence education: This group just received a standard driving manual }(\mathrm{n}=12,062) \\
\text { Correspondence education: This group received the driving manual and 'at home' test }(\mathrm{n}=11,744) . \\
\text { Correspondence education: This group received the driving manual and a 'station' written test }(\mathrm{n}=11,714) \\
\text { Control: This group received the standard renewal notice and vision test }(\mathrm{n}=12,108) .\end{array}$ \\
\hline
\end{tabular}

Outcomes After 24 months, the number of participants involved in a crash and the number committing major and minor traffic offences.

Notes
A total of 58,352 drivers were originally allocated to treatment group, however, those who did not actually
renew their licence within the specified 90 days were not included in the analysis.

\section{Risk of bias}

\begin{tabular}{l|ll}
\hline Item & Authors' judgement & Description \\
\hline Allocation concealment? & No & C - Inadequate \\
\hline
\end{tabular}

DDC - Defensive Driving Course

DDSL - Division of Driver Safety and Licensing

DMV - Department of Motor Vehicles

DUI - Driving under the influence 
GEM - Group Education Meeting

HI/PRI - Home Instruction/Point Reduction Incentive

MSL - Maximum Speed Law

NSC - National Safety Council

NTSI - National Traffic Safety Institute's Traffic Violator Workshop

TIPS - Training in Perceptual Strategy

TSS - Traffic Safety School

UDIS - Uniform Driver Improvement School

\section{Characteristics of excluded studies [ordered by study ID]}

\begin{tabular}{|c|c|}
\hline Study & Reason for exclusion \\
\hline Campbell 1959 & Assignment was not randomised. \\
\hline Carcary 2001 & Controlled before/after, no evidence of random allocation. \\
\hline Gregersen 1996 & Participants were yet to obtain a full driving licence. \\
\hline Henderson 1967 & Controlled before/after, no evidence of random allocation. \\
\hline Kaestner 1968 & $\begin{array}{l}\text { Participants were a second year sample of those from Kaestner 1967, who had driven the first } 12 \text { months without } \\
\text { crash or traffic offence. }\end{array}$ \\
\hline Kaestner 1983 & The two intervention groups both received types of group driver education. \\
\hline Kayser 1995 & Participants were yet to obtain a full driving licence. \\
\hline Lynn 1982d & The two intervention groups both received the same form (correspondence) of driver education. \\
\hline McKnight 1997 & The two intervention groups both received types of group driver education. \\
\hline Mills 1996 & Controlled before/after, no evidence of random allocation. \\
\hline Mollenhauer 1997 & Controlled before/after, no evidence of random allocation. \\
\hline Regan 1998a & Not all participants were full driving licence holders. \\
\hline Regan 1998b & All study groups received some form of driver education. \\
\hline Schupack 1975 & Assignment was not adequately randomised. Classes not individuals were allocated to the treatment groups. \\
\hline Strang 1982 & Participants were yet to obtain a full driving licence. \\
\hline Whittenburg 1974 & Controlled before/after with matched experimental and control groups. \\
\hline
\end{tabular}


DATA AND ANALYSES

Comparison 1. Driver education versus no driver education

\begin{tabular}{lcclc} 
Outcome or subgroup title & $\begin{array}{c}\text { No. of } \\
\text { studies }\end{array}$ & $\begin{array}{c}\text { No. of } \\
\text { participants }\end{array}$ & Statistical method & Effect size \\
\hline 1 Offences & 19 & 309624 & Risk Ratio (M-H, Random, 95\% CI) & $0.96[0.94,0.98]$ \\
1.1 Remedial driver education & 18 & 261996 & Risk Ratio (M-H, Random, 95\% CI) & $0.96[0.94,0.98]$ \\
1.2 Advanced driver education & 1 & 47628 & Risk Ratio (M-H, Random, 95\% CI) & $0.98[0.93,1.03]$ \\
2 Crashes & 15 & 282704 & Risk Ratio (M-H, Random, 95\% CI) & $0.98[0.96,1.01]$ \\
2.1 Remedial driver education & 13 & 234943 & Risk Ratio (M-H, Random, 95\% CI) & $0.98[0.96,1.01]$ \\
2.2 Advanced driver education & 2 & 47761 & Risk Ratio (M-H, Random, 95\% CI) & $0.99[0.93,1.05]$ \\
3 Injury crashes & 4 & 59089 & Risk Ratio (M-H, Random, 95\% CI) & $1.12[0.88,1.41]$ \\
3.1 Remedial driver education & 3 & 57449 & Risk Ratio (M-H, Random, 95\% CI) & $1.17[0.89,1.54]$ \\
3.2 Advanced driver education & 1 & 1640 & Risk Ratio (M-H, Random, 95\% CI) & $0.94[0.74,1.20]$ \\
\hline
\end{tabular}

Comparison 2. Correspondence driver education versus no driver education

\begin{tabular}{lcclc} 
Outcome or subgroup title & $\begin{array}{c}\text { No. of } \\
\text { studies }\end{array}$ & $\begin{array}{c}\text { No. of } \\
\text { participants }\end{array}$ & Statistical method & Effect size \\
\hline 1 Offences & 9 & 121726 & Risk Ratio (M-H, Random, 95\% CI) & $0.98[0.97,0.99]$ \\
1.1 Remedial driver education & 8 & 74098 & Risk Ratio (M-H, Random, 95\% CI) & $0.98[0.97,0.99]$ \\
1.2 Advanced driver education & 1 & 47628 & Risk Ratio (M-H, Random, 95\% CI) & $0.98[0.93,1.03]$ \\
2 Crashes & 7 & 111538 & Risk Ratio (M-H, Random, 95\% CI) & $0.98[0.95,1.01]$ \\
2.1 Remedial driver education & 6 & 63910 & Risk Ratio (M-H, Random, 95\% CI) & $0.97[0.93,1.02]$ \\
2.2 Advanced driver education & 1 & 47628 & Risk Ratio (M-H, Random, 95\% CI) & $0.99[0.93,1.05]$ \\
3 Injury crashes & 1 & 24000 & Risk Ratio (M-H, Random, 95\% CI) & $0.94[0.81,1.09]$ \\
3.1 Remedial driver education & 1 & 24000 & Risk Ratio (M-H, Random, 95\% CI) & $0.94[0.81,1.09]$ \\
3.2 Advanced driver education & 0 & 0 & Risk Ratio (M-H, Random, 95\% CI) & Not estimable \\
\hline
\end{tabular}

Comparison 3. Group driver education versus no driver education

\begin{tabular}{lccll} 
Outcome or subgroup title & $\begin{array}{c}\text { No. of } \\
\text { studies }\end{array}$ & $\begin{array}{c}\text { No. of } \\
\text { participants }\end{array}$ & Statistical method & Effect size \\
\hline 1 Offences & 11 & 69501 & Risk Ratio (M-H, Random, 95\% CI) & $0.95[0.92,0.97]$ \\
1.1 Remedial driver education & 11 & 69501 & Risk Ratio (M-H, Random, 95\% CI) & $0.95[0.92,0.97]$ \\
2 Crashes & 9 & 67854 & Risk Ratio (M-H, Random, 95\% CI) & $0.97[0.93,1.02]$ \\
2.1 Remedial driver education & 8 & 67721 & Risk Ratio (M-H, Random, 95\% CI) & $0.98[0.93,1.02]$ \\
2.2 Advanced driver education & 1 & 133 & Risk Ratio (M-H, Random, 95\% CI) & $0.75[0.30,1.88]$ \\
3 Injury crashes & 3 & 28973 & Risk Ratio (M-H, Random, 95\% CI) & $1.02[0.93,1.13]$ \\
3.1 Remedial driver education & 2 & 27333 & Risk Ratio (M-H, Random, 95\% CI) & $1.04[0.94,1.16]$ \\
3.2 Advanced driver education & 1 & 1640 & Risk Ratio (M-H, Random, 95\% CI) & $0.94[0.74,1.20]$ \\
\hline Post-licence driver education for the prevention of road traffic crashes (Review) & $\mathbf{3 2}$ \\
Copyright $\odot$ 2008 The Cochrane Collaboration. Published by John Wiley \& Sons, Ltd. &
\end{tabular}




\begin{tabular}{cccll} 
Outcome or subgroup title & $\begin{array}{c}\text { No. of } \\
\text { studies }\end{array}$ & $\begin{array}{c}\text { No. of } \\
\text { participants }\end{array}$ & Statistical method & Effect size \\
\hline 1 Offences & 7 & 136478 & Risk Ratio (M-H, Random, 95\% CI) & $0.95[0.91,1.00]$ \\
1.1 Remedial driver education & 7 & 136478 & Risk Ratio (M-H, Random, 95\% CI) & $0.95[0.91,1.00]$ \\
1.2 Advanced driver education & 0 & 0 & Risk Ratio (M-H, Random, 95\% CI) & Not estimable \\
2 Crashes & 6 & 133090 & Risk Ratio (M-H, Random, 95\% CI) & $0.99[0.96,1.03]$ \\
2.1 Remedial driver education & 6 & 133090 & Risk Ratio (M-H, Random, 95\% CI) & $0.99[0.96,1.03]$ \\
2.2 Advanced driver education & 0 & 0 & Risk Ratio (M-H, Random, 95\% CI) & Not estimable \\
3 Injury crashes & 1 & 12479 & Risk Ratio (M-H, Random, 95\% CI) & $1.18[1.00,1.38]$ \\
3.1 Remedial driver education & 1 & 12479 & Risk Ratio (M-H, Random, 95\% CI) & $1.18[1.00,1.38]$ \\
3.2 Advanced driver education & 0 & 0 & Risk Ratio (M-H, Random, 95\% CI) & Not estimable \\
\hline
\end{tabular}

\section{Analysis I.I. Comparison I Driver education versus no driver education, Outcome I Offences.}

Review: Post-licence driver education for the prevention of road traffic crashes

Comparison: I Driver education versus no driver education

Outcome: I Offences

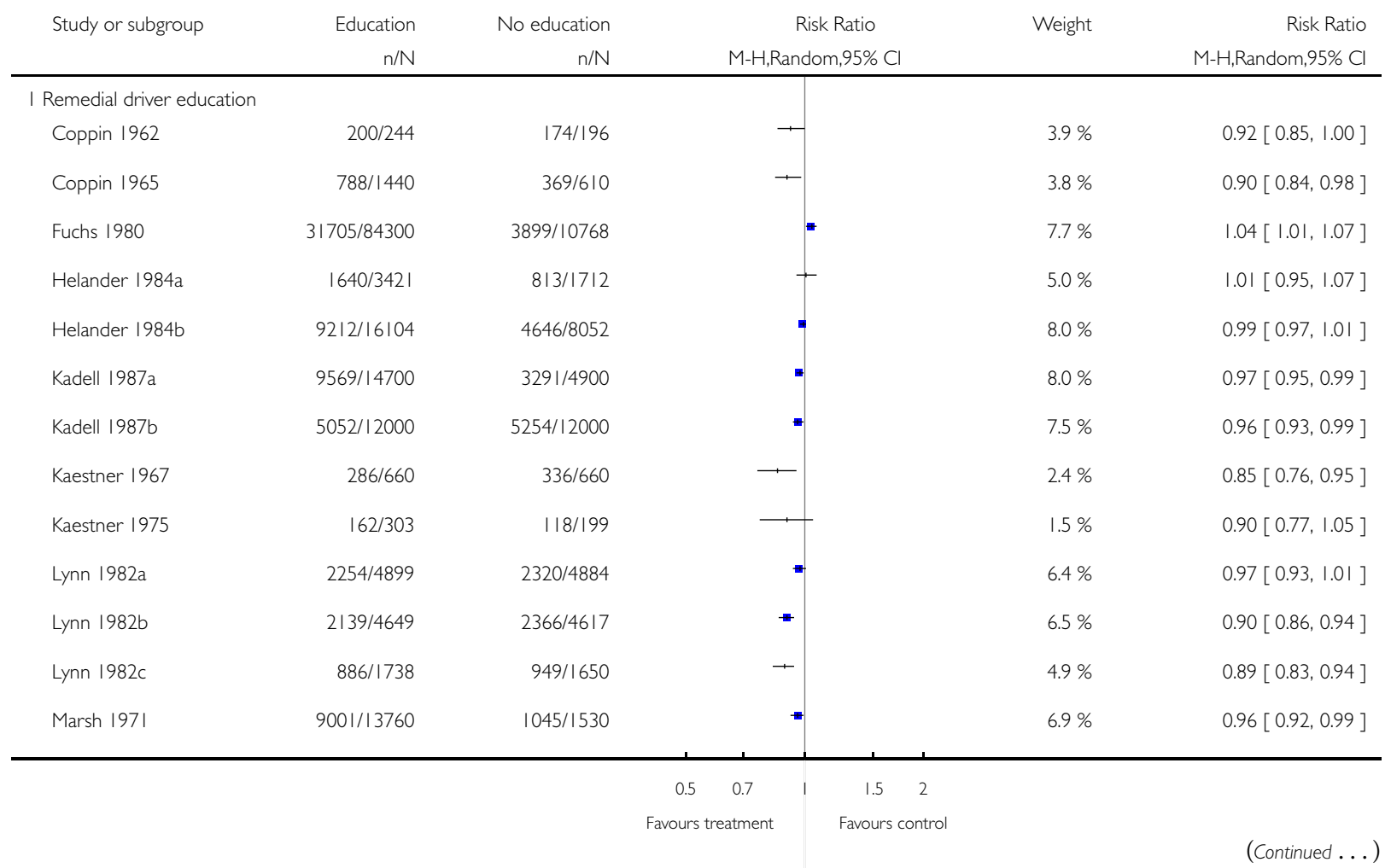




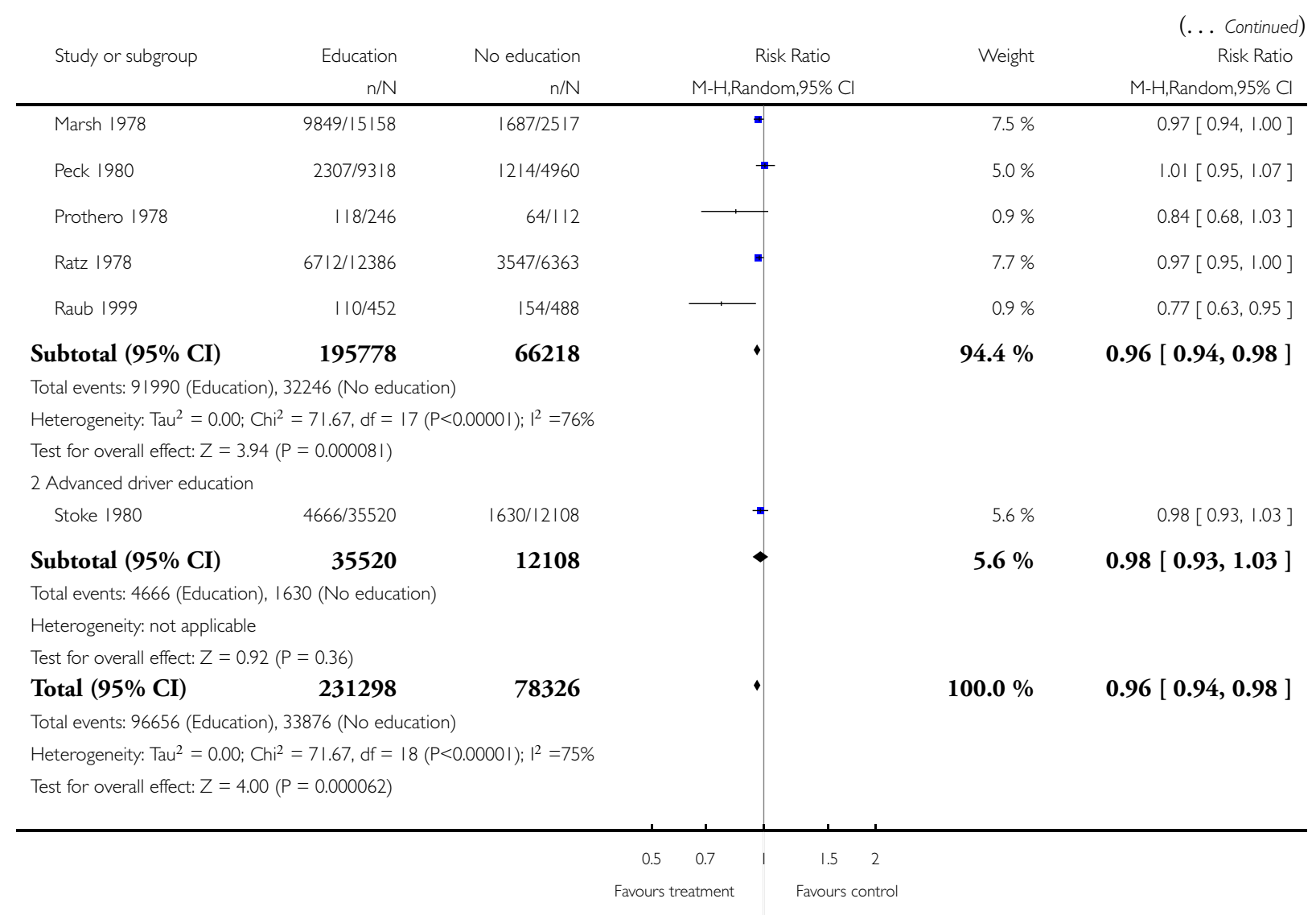




\section{Analysis I.2. Comparison I Driver education versus no driver education, Outcome 2 Crashes.}

Review: Post-licence driver education for the prevention of road traffic crashes

Comparison: I Driver education versus no driver education

Outcome: 2 Crashes

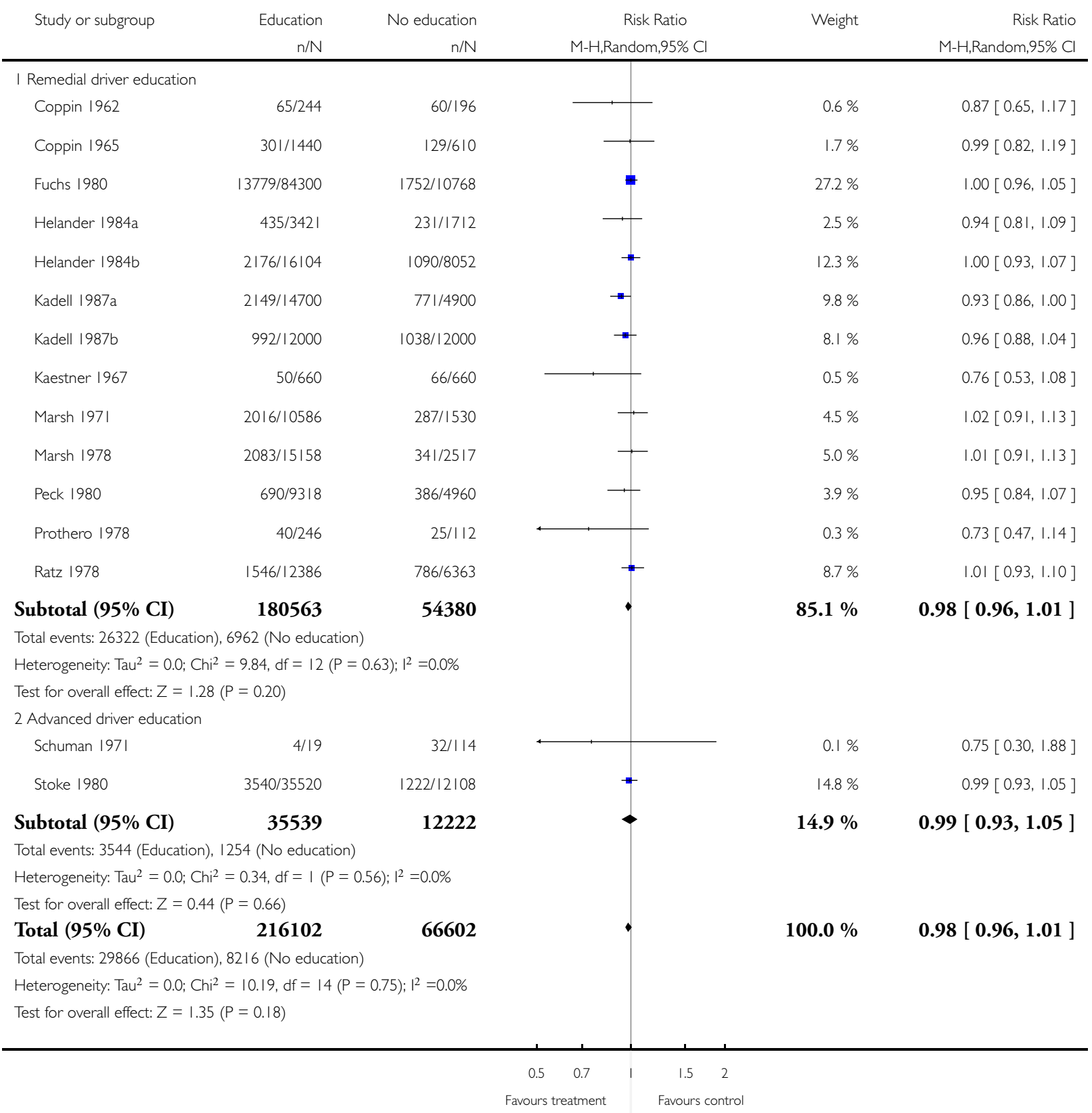


Analysis I.3. Comparison I Driver education versus no driver education, Outcome 3 Injury crashes.

Review: Post-licence driver education for the prevention of road traffic crashes

Comparison: I Driver education versus no driver education

Outcome: 3 Injury crashes

$\begin{array}{llll}\text { Study or subgroup } & \text { Education } & \text { No education } & \text { Risk Ratio }\end{array}$

$\mathrm{n} / \mathrm{N} \quad \mathrm{n} / \mathrm{N} \quad \mathrm{M}-\mathrm{H}$, Random,95\% Cl M-H,Random, $95 \% \mathrm{Cl}$

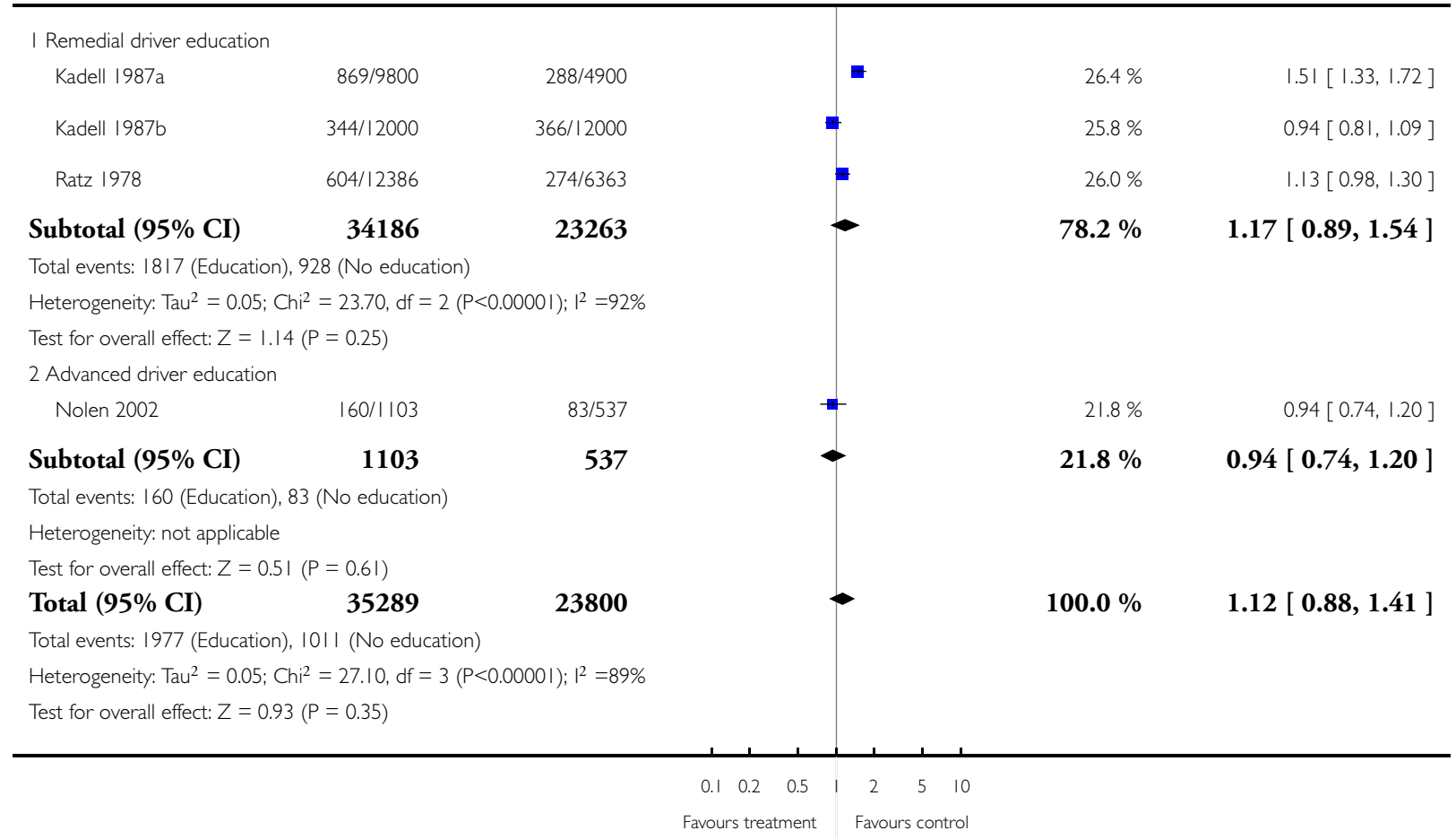


Analysis 2.I. Comparison 2 Correspondence driver education versus no driver education, Outcome I Offences.

Review: Post-licence driver education for the prevention of road traffic crashes

Comparison: 2 Correspondence driver education versus no driver education

Outcome: I Offences

$\begin{array}{llll}\text { Study or subgroup } & \text { Education } & \text { No education } & \text { Risk Ratio }\end{array}$

M-H Random.95\% Cl M-H Random, $95 \%$ Clight

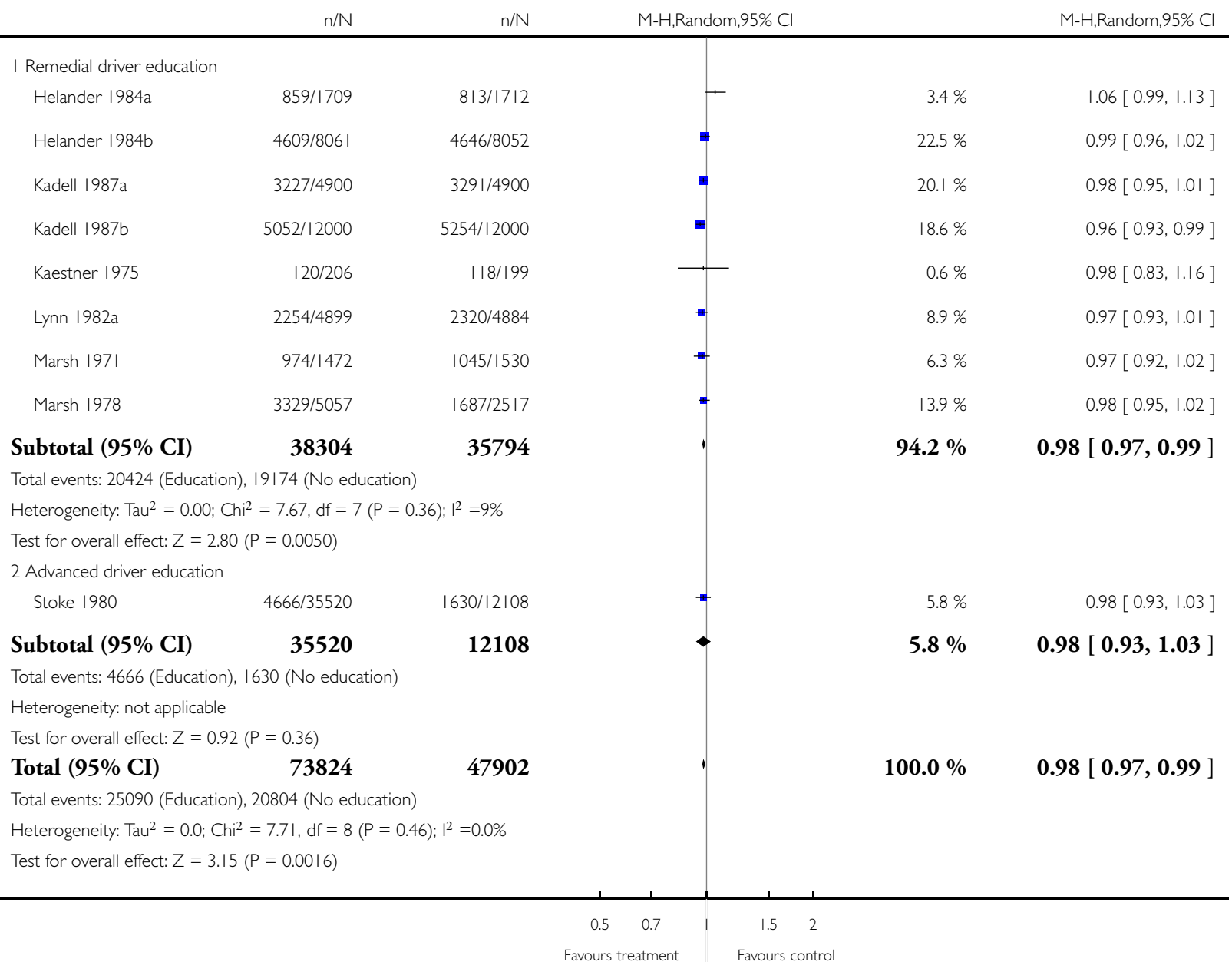


Analysis 2.2. Comparison 2 Correspondence driver education versus no driver education, Outcome 2 Crashes.

Review: Post-licence driver education for the prevention of road traffic crashes

Comparison: 2 Correspondence driver education versus no driver education

Outcome: 2 Crashes

$\begin{array}{llll}\text { Study or subgroup } & \text { Education } & \text { No education Ratio } & \text { Weight }\end{array}$

$\mathrm{n} / \mathrm{N}$

M-H,Random,95\% C

$\mathrm{M}-\mathrm{H}, \mathrm{Random}, 95 \% \mathrm{Cl}$

I Remedial driver education

Helander 1984a

$231 / 1709$

$231 / 1712$

Helander 1984b

| | $4 / 806$ |

1090/8052

Kadell 1987a

$700 / 4900$

$771 / 4900$

Kadell 1987b

$992 / 12000$

1038/12000

Marsh 1971

276/1472

287/1530

Marsh 1978

678/5057

$341 / 2517$

33199

30711

Subtotal (95\% CI)

Total events: 399। (Education), 3758 (No education)
Heterogeneity: $\mathrm{Tau}^{2}=0.0 ; \mathrm{Chi}^{2}=4.03, \mathrm{df}=5(\mathrm{P}=0.55) ; \mathrm{I}^{2}=0.0 \%$

Test for overall effect: $Z=1.20(P=0.23)$

2 Advanced driver education

Stoke 1980

$3540 / 35520$

$1222 / 12108$

$31.5 \%$

$0.99[0.93,1.05]$

Subtotal (95\% CI)

35520

Total events: 3540 (Education), 1222 (No education)

Heterogeneity: not applicable

Test for overall effect: $Z=0.40(P=0.69)$

Total (95\% CI)

68719

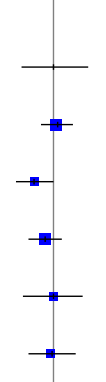

$4.2 \%$

$19.9 \%$

$13.5 \%$

$17.3 \%$

$5.4 \%$

$8.2 \%$

$68.5 \%$

$0.97[0.93,1.02]$

Total events: 753। (Education), 4980 (No education)

Heterogeneity: $\mathrm{Tau}^{2}=0.0 ; \mathrm{Chi}^{2}=4.14, \mathrm{df}=6(\mathrm{P}=0.66) ; \mathrm{I}^{2}=0.0 \%$

Test for overall effect: $Z=1.22(P=0.22)$
12108

$31.5 \%$

$0.99[0.93,1.05]$

42819

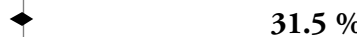

$100.0 \%$

$0.98[0.95,1.01]$ 
Analysis 2.3. Comparison 2 Correspondence driver education versus no driver education, Outcome 3 Injury crashes.

Review: Post-licence driver education for the prevention of road traffic crashes

Comparison: 2 Correspondence driver education versus no driver education

Outcome: 3 Injury crashes

Education No education

Risk Ratio

Weight

Risk Ratio

I Remedial driver education

Kadell 1987b

$344 / 12000$

$366 / 12000$

M-H,Random,95\% Cl

$\mathrm{M}-\mathrm{H}, \mathrm{Random}, 95 \% \mathrm{Cl}$

Subtotal (95\% CI)

12000

12000

$100.0 \%$

$0.94[0.81,1.09]$

Total events: 344 (Education), 366 (No education)

Heterogeneity: not applicable

Test for overall effect: $Z=0.84(P=0.40)$

2 Advanced driver education

Subtotal (95\% CI)

$\mathbf{0}$

Total events: 0 (Education), 0 (No education)

Heterogeneity: not applicable

Test for overall effect: not applicable

Total (95\% CI)

12000

12000

$100.0 \%$

$0.94[0.81,1.09]$

Total events: 344 (Education), 366 (No education)

Heterogeneity: not applicable

Test for overall effect: $Z=0.84(P=0.40)$

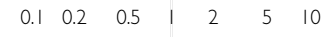

Favours treatment Favours control 
Analysis 3.I. Comparison 3 Group driver education versus no driver education, Outcome I Offences.

Review: Post-licence driver education for the prevention of road traffic crashes

Comparison: 3 Group driver education versus no driver education

Outcome: I Offences

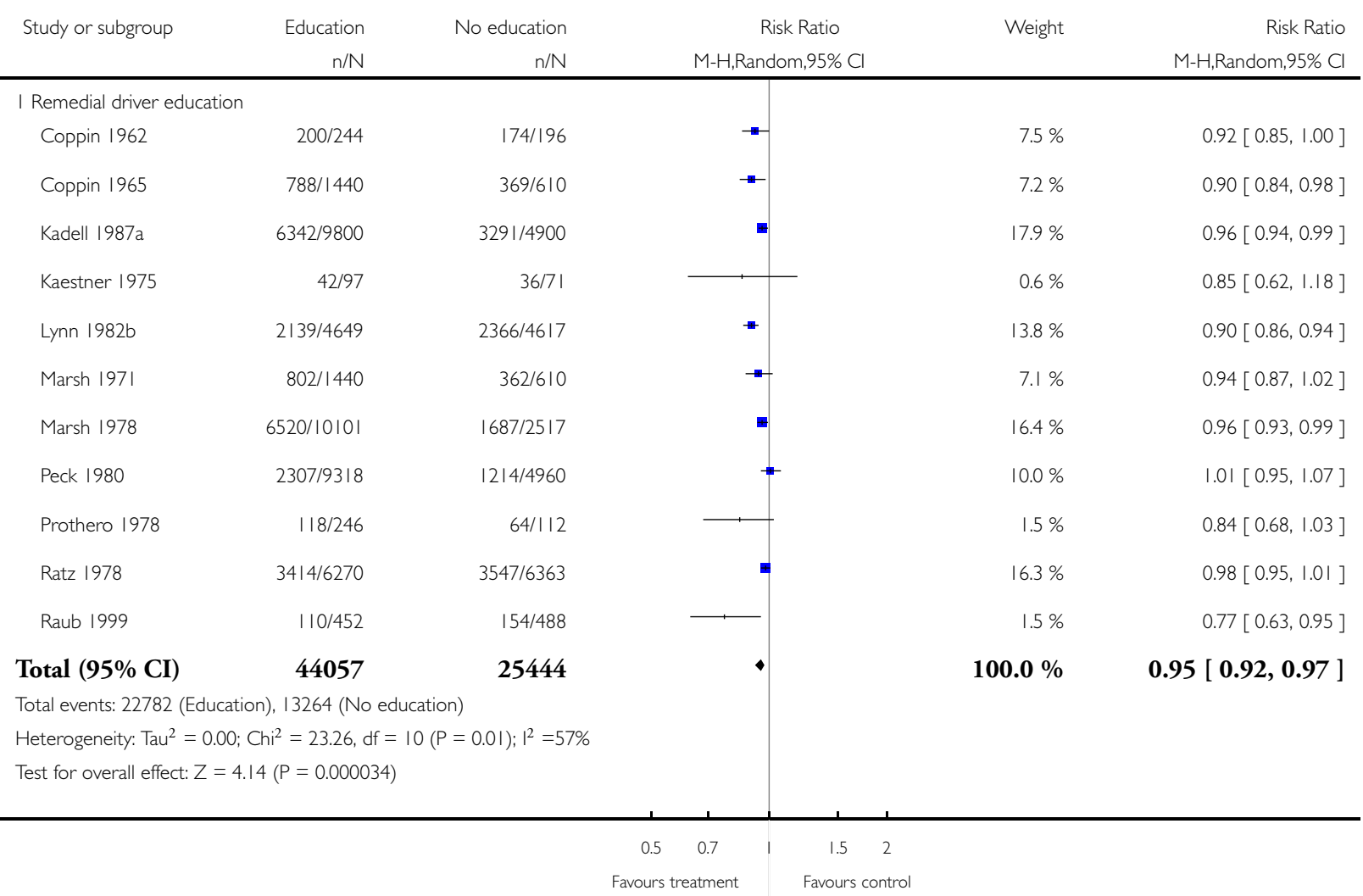


Analysis 3.2. Comparison 3 Group driver education versus no driver education, Outcome 2 Crashes.

Review: Post-licence driver education for the prevention of road traffic crashes

Comparison: 3 Group driver education versus no driver education

Outcome: 2 Crashes

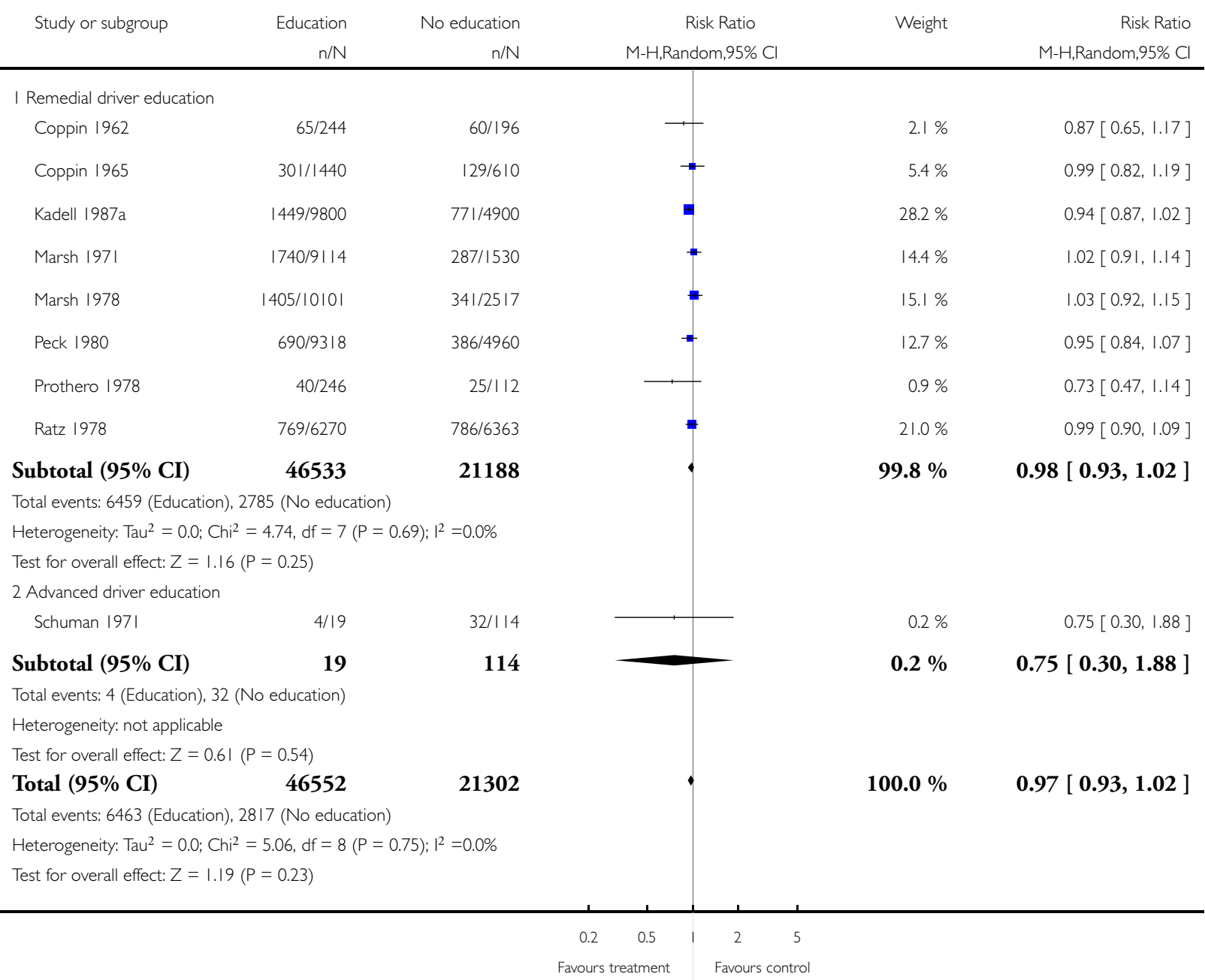


Analysis 3.3. Comparison 3 Group driver education versus no driver education, Outcome 3 Injury crashes.

Review: Post-licence driver education for the prevention of road traffic crashes

Comparison: 3 Group driver education versus no driver education

Outcome: 3 Injury crashes

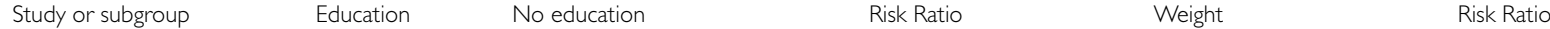

$\mathrm{n} / \mathrm{N} \quad \mathrm{n} / \mathrm{N} \quad \mathrm{M}-\mathrm{H}$, Random,95\% Cl M-H,Random,95\% Cl

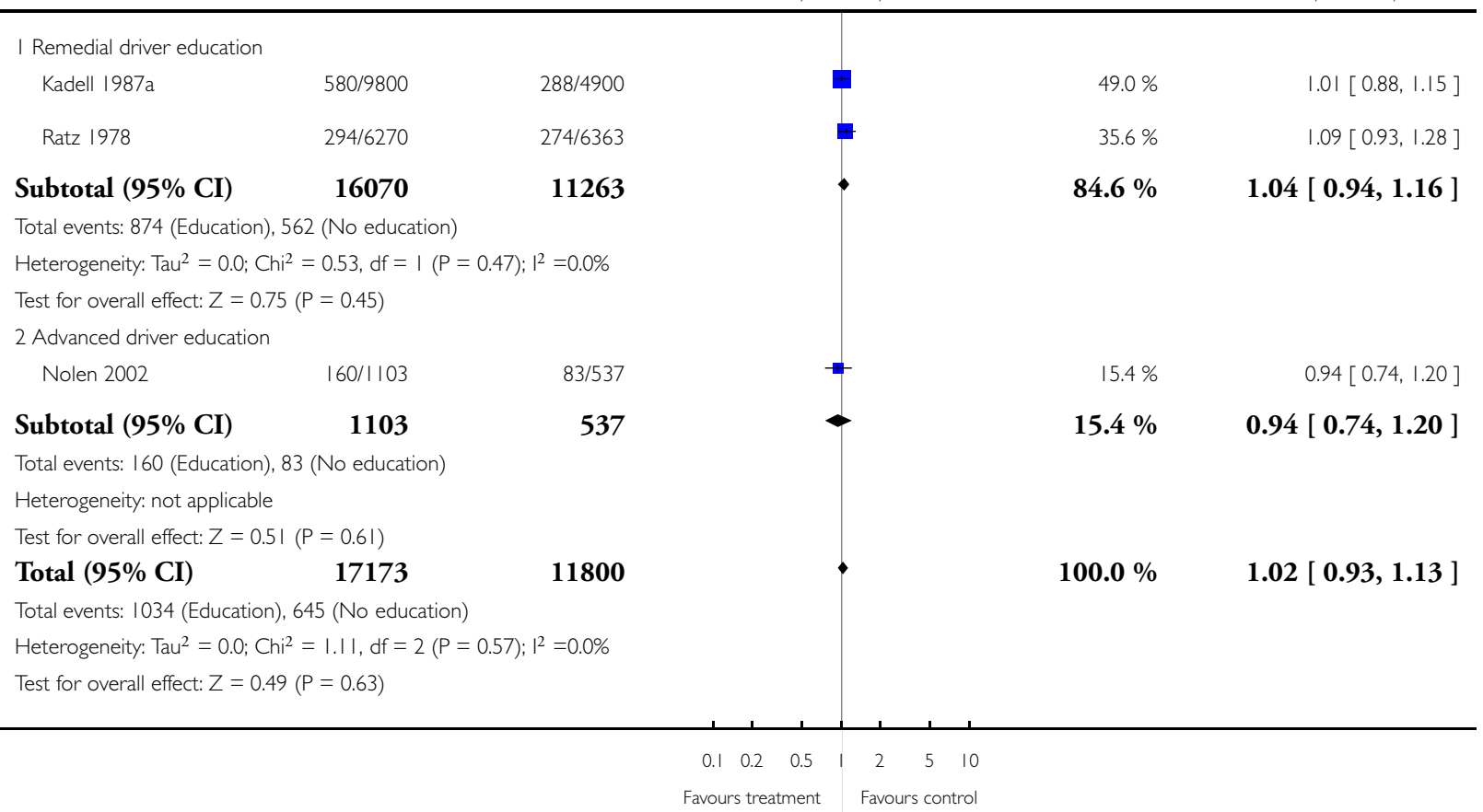


Analysis 4.I. Comparison 4 Individual driver education versus no driver education, Outcome I Offences.

Review: Post-licence driver education for the prevention of road traffic crashes

Comparison: 4 Individual driver education versus no driver education

Outcome: I Offences

Education No education

Risk Ratio

Weight

Risk Ratio

| Remedial driver education

Fuchs 1980

$31705 / 84300$

$n / \mathrm{N}$

M-H,Random,95\% Cl

$\mathrm{M}-\mathrm{H}, \mathrm{Random}, 95 \% \mathrm{Cl}$

Helander 1984a

$781 / 1712$

$3899 / 10768$

Helander 1984b

$4603 / 8043$

$813 / 1712$

4646/8052

Kaestner 1967

$286 / 660$

$336 / 660$

Lynn 1982c

$886 / 1738$

$949 / 1650$

Marsh 1971

$1987 / 3174$

1045/1530

Ratz 1978

$3298 / 6116$

$3547 / 6363$

105743

30735

Subtotal (95\% CI)

Total events: 43546 (Education), 15235 (No education)

Heterogeneity: $\mathrm{Tau}^{2}=0.00 ; \mathrm{Chi}^{2}=46.09, \mathrm{df}=6(\mathrm{P}<0.0000 \mathrm{I}) ; \mathrm{I}^{2}=87 \%$

Test for overall effect: $Z=2.14(P=0.032)$

2 Advanced driver education

Subtotal (95\% CI)

$\mathbf{0}$

$\mathbf{0}$

Total events: 0 (Education), 0 (No education)

Heterogeneity: not applicable

Test for overall effect: not applicable

Total (95\% CI) 105743

30735

Total events: 43546 (Education), 15235 (No education)

Heterogeneity: $\mathrm{Tau}^{2}=0.00 ; \mathrm{Chi}^{2}=46.09, \mathrm{df}=6(\mathrm{P}<0.0000 \mathrm{I}) ; \mathrm{I}^{2}=87 \%$

Test for overall effect: $Z=2.14(P=0.032)$

$\begin{array}{lll}-17.1 \% & 1.04[1.01,1.07] \\ 12.3 \% & 0.96[0.89,1.03] \\ -17.1 \% & 0.99[0.97,1.02] \\ 7.1 \% & 0.85[0.76,0.95] \\ 13.4 \% & 0.89[0.83,0.94] \\ 15.5 \% & 0.92[0.88,0.96] \\ 16.6 \% & 0.97[0.94,1.00]\end{array}$

$100.0 \%$

$0.95[0.91,1.00]$

$0.0 \%$

$0.0[0.0,0.0]$

$100.0 \%$

$0.95[0.91,1.00]$ 
Analysis 4.2. Comparison 4 Individual driver education versus no driver education, Outcome 2 Crashes.

Review: Post-licence driver education for the prevention of road traffic crashes

Comparison: 4 Individual driver education versus no driver education

Outcome: 2 Crashes

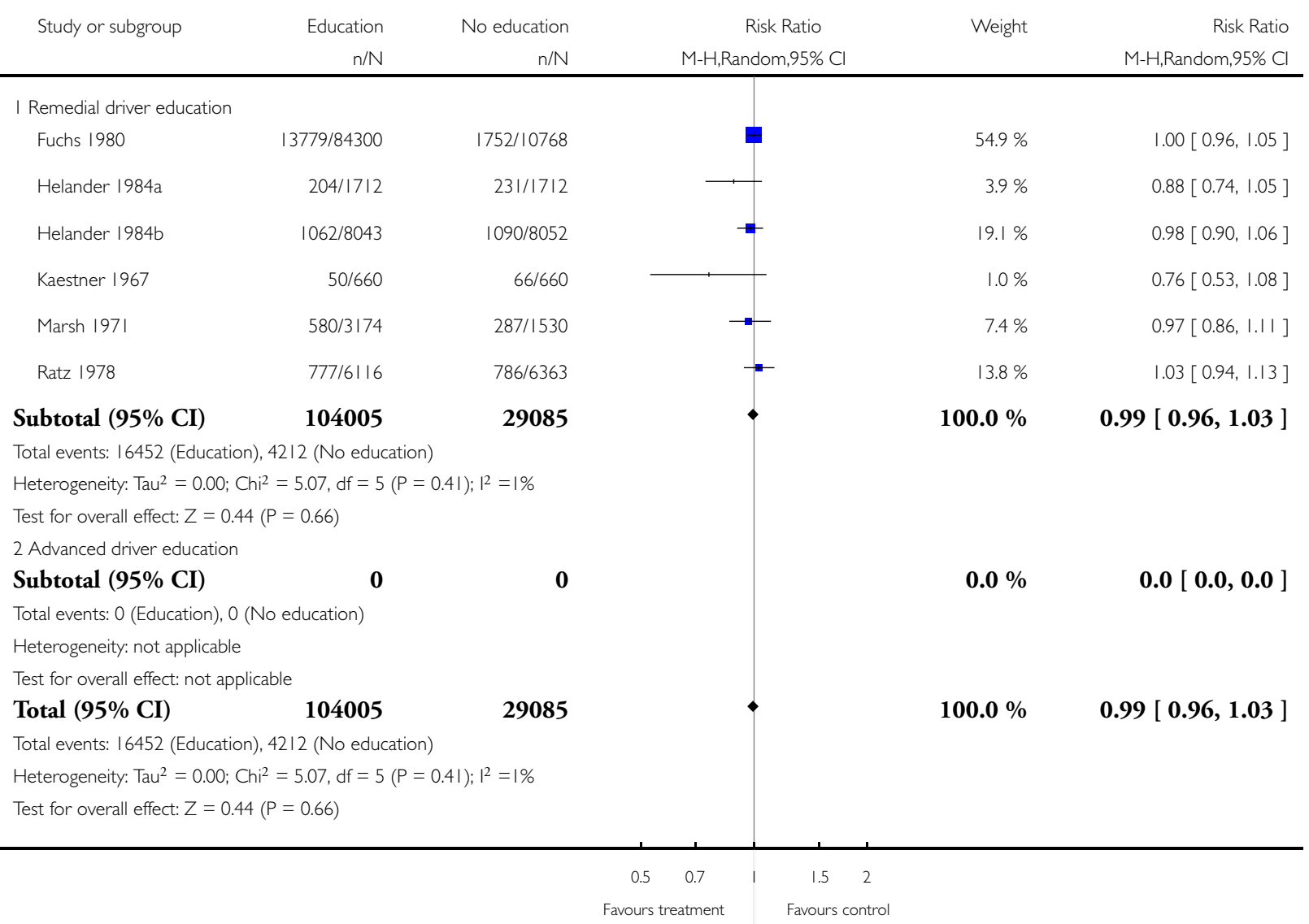


Analysis 4.3. Comparison 4 Individual driver education versus no driver education, Outcome 3 Injury crashes.

Review: Post-licence driver education for the prevention of road traffic crashes

Comparison: 4 Individual driver education versus no driver education

Outcome: 3 Injury crashes

$\begin{array}{llll}\text { Study or subgroup } \quad \text { Education } & \text { No education } & \text { Wisk Ratio }\end{array}$

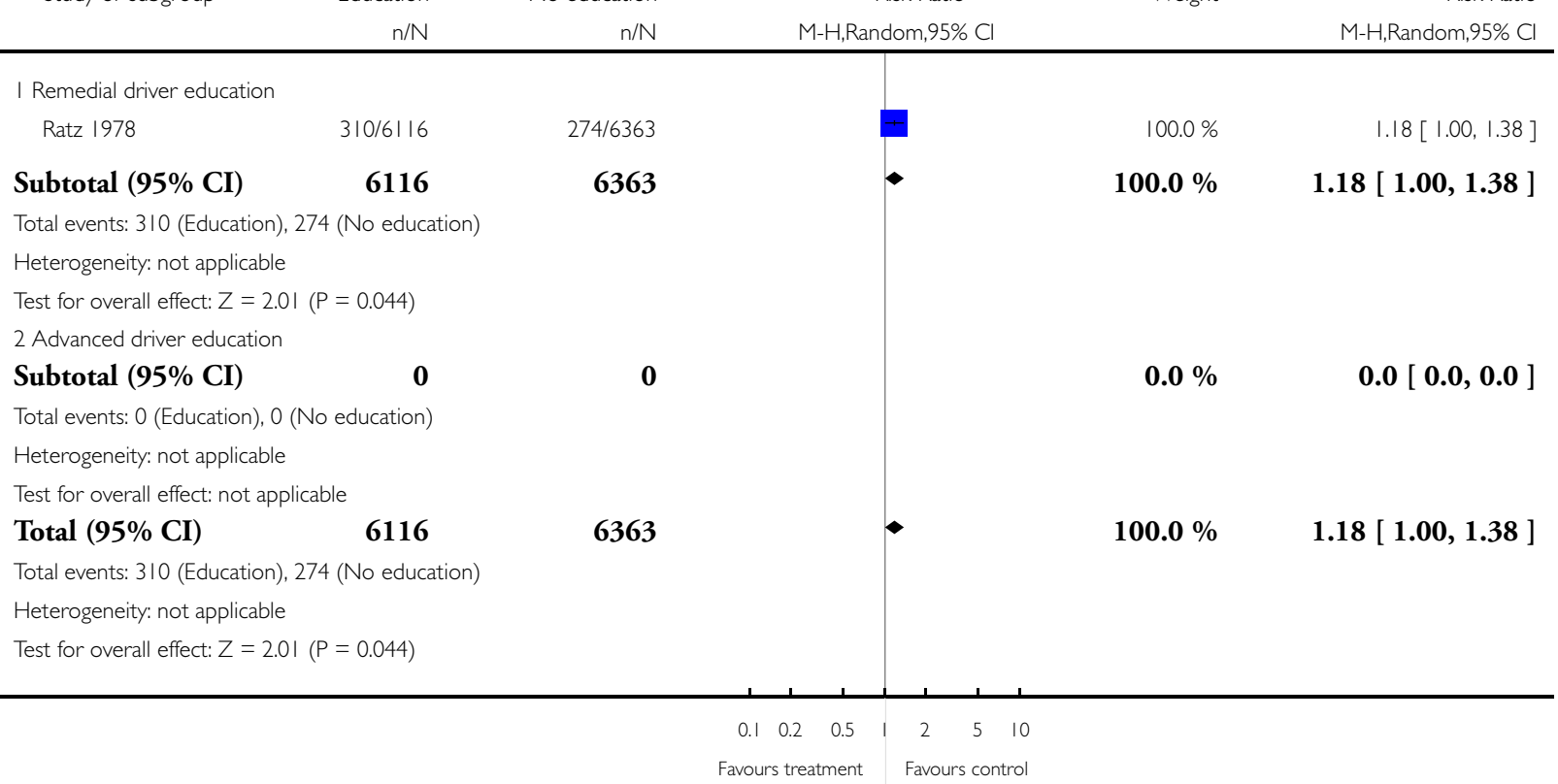

\section{A P PENDICES}

\section{Appendix I. Detailed search strategies}

Cochrane Injuries Group Specialized Register (searched October 14, 2005)

(driver or driving) and (education or improvement or training or qualif or skill or abilit or program or course)

Cochrane Library Issue 3, 2005

\#1 AUTOMOBILE DRIVING:Me

\#2 (qualif* NEAR driver) OR (qualif* NEAR driving)

\#3 (skill* NEAR driver) OR (skill* NEAR driving)

\#4 (abilit* NEAR driver) OR (abilit* NEAR driver)

\#5 (program* NEAR driver) OR (program* NEAR driving)

\#6 (education NEAR driver) OR (education NEAR driving)

\#7 (improvement NEAR driver) OR (improvement NEAR driving)

\#8 (training NEAR driver) OR (training NEAR driving)

\#9 driving course*

\#10 post NEXT licen*

Post-licence driver education for the prevention of road traffic crashes (Review)

Copyright (@) 2008 The Cochrane Collaboration. Published by John Wiley \& Sons, Ltd. 
\#11 traffic NEAR violat*

\#12 1 OR 2 OR 3 OR 4 OR 5 OR 6 OR 7 OR 8 OR 9 OR 10 OR 11

\#13 ACCIDENTS-TRAFFIC:Me

\#14 ACCIDENT PREVENTION:Me

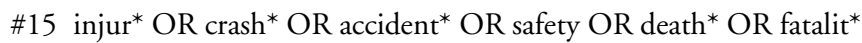

\#16 (15:TI) OR (15:AB)

\#17 13 OR 14 OR 16

\#18 explode MOTOR VEHICLES:Me

\#19 motor vehicle* OR automobile* OR car OR cars OR lorry OR lorries OR van OR vans OR truck* OR motorbike* OR motorcycle* OR taxi* OR ambulance* OR fire engine* OR tractor* OR jeep* OR minibus* OR coach* OR bus OR buses

\#20 (19:TI) OR (19:AB)

\#21 12 AND 17 AND 20

TRANSPORT (to issue 6, 2005) (Silverplatter, CD version)

1. (qualif* NEAR3 driver) OR (qualif* NEAR3 driving)

2. (skill* NEAR3 driver) OR (skill* NEAR3 driving)

3. (abilit* NEAR3 driver) OR (abilit* NEAR3 driver)

4. (program* NEAR3 driver) OR (program* NEAR3 driving)

5. (education NEAR3 driver) OR (education NEAR3 driving)

6. (improvement NEAR3 driver) OR (improvement NEAR3 driving)

7. (training NEAR3 driver) OR (training NEAR3 driving)

8. driving course*

9. 1 OR 2 OR 3 OR 4 OR 5 OR 6 OR 7 OR 8

10. (9 in ti) OR ( 9 in ab)

11. driver education* in de

12. driver training* in de

13. driver improvement* in de

14. advanced driver education in de

15. defensive driving

16. 11 OR 12 OR 13 OR 14 OR 15

17. 10 OR 16

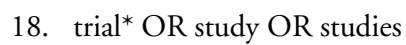

19. 16 AND 17

Australian Transport Index (to Jan, 2002)

1. (improv* near3 driver) OR (improv* near3 driving)

2. (training near 3 driver) or (training near 3 driving)

3. (educat* near 3 driver) or (educat* near3 driving)

4. (program* near3 driver) or (program* near 3 driving)

5. (abilit* near3 driver) or (abilit* near3 driving)

6. (skill* near3 driver) or (skill* near3 driving)

7. (qualif* near3 driver) or (qualif* near3 driving)

8. defensive driving

9. 1 or 2 or 3 or 4 or 5 or 6 or 7 or 8

10. motor vehicle* or automobile* or car or cars or lorry or lorries or van or vans or truck* or motorbike* or motorcycle* or taxi* or $^{*}$ ambulance* or fire engine* or tractor* or jeep* or minibus* or coach* or bus or buses

11. (10 in ti) or (10 in ab)

12. injur* or crash* or accident* or safety or death* or fatalit*

13. (12 in ti $)$ or $(12$ in ab)

14. 9 and 11 and 13

15. trial* or study or studies or randomi*

16. 14 and 15

MEDLINE 1966 to 2005/October week 1 (Silverplatter; Webspirs 5 version)

\#1 explode "Automobile-Driving" / all SUBHEADINGS in MIME,MJME

\#2 ( ((abilit* near3 driver*) or (abilit* near3 driver*)) in AB )

Post-licence driver education for the prevention of road traffic crashes (Review)

Copyright $(2008$ The Cochrane Collaboration. Published by John Wiley \& Sons, Ltd. 
\#3 ( ((skill* near3 driver*) or (skill* near3 driving $))$ in AB )

\#4 (( qualif* near3 driver*) or (qualif* near3 driving) ) in $A B)$

\#5 (((program* near3 driver*) or (program* near3 driving)) in $A B)$

\#6 ( ((educat* near3 driver*) or (educat* near3 driving)) in $\mathrm{AB})$

\#7 (( improv* $^{*}$ near3 driver* $\left.{ }^{*}\right)$ or (improv* near3 driving $\left.)\right)$ in $\left.A B\right)$

$\# 8 \quad$ ( ((training near3 driver*) or (training near3 driving $))$ in $\mathrm{AB})$

\#9 ( (driving next course* $)$ in $\mathrm{AB}$ )or( (driving next course* $)$ in TI )

\#10 ( (post adj licen*) in AB )or( (post adj licen*) in TI)

\#11 ( (traffic near3 violat*) in AB )or( (traffic near3 violat $\left.{ }^{*}\right)$ in TI )

$\# 12 \# 1$ or $\# 2$ or \#3 or \#4 or \#5 or \#6 or \#7 or \#8 or \#9 or \#10 or \#11

\#13 explode "Accidents-Traffic" / all SUBHEADINGS in MIME,MJME

\#14 explode "Accident-Prevention" / all SUBHEADINGS in MIME,MJME

\#15 ( (injur* or crash* or accident* or safety or death* or fatalit*) in AB )or( (injur* or crash* or accident* or safety or death* or fatalit*) in TI )

$\# 16$ \#13 or \#14 or \#15

\#17 explode "Motor-Vehicles" / all SUBHEADINGS in MIME,MJME

\#18 ( (motor vehicle* or automobile* or car or cars or lorry or lorries or van or vans or truck* or motorbike* or motorcycle* or taxi* or ambulance* or fire engine* or tractor* $^{*}$ or jeep* or minibus* or coach* or bus or buses) in $\mathrm{AB}$ ) or ( (motor vehicle* or automobile* or car or cars or lorry or lorries or van or vans or truck* or motorbike* or motorcycle* or taxi* or ambulance* or fire engine* or tractor* or jeep* or minibus* or coach* or bus or buses) in TI )

\#19 \#17 or \#18

$\# 20 \# 12$ and \#16 and \#19

\section{Embase 1980 to 2002/Feb (Ovid)}

1. $\quad$ exp Motor Vehicle

2. (motor vehicle\$ OR automobile\$ OR car OR cars OR lorry OR truck\$ OR motorbike\$ OR motorcycle\$ OR taxi\$ OR ambulance\$ OR fire engine\$ OR tractor\$ OR jeep\$ OR minibus\$ OR coach\$ OR bus OR buses).ti,ab

3. 1 or 2

4. $\quad$ exp Car Driving

5. $\quad \exp$ Accident Prevention

6. $\quad$ exp Traffic Accident

7. (injur\$ OR crash\$ OR accident\$ OR safety OR death\$ OR fatalit\$).ti,ab

8. driv $\$$ adj3 (qualif\$ or abilit $\$$ or program $\$$ or educat $\$$ or improv\$ or course\$

9. (training adj3 driver\$)

10. driving adj 3 post adj 3 licen $\$$

11. traffic adj3 violat $\$$

12. 4 or 5 or 6 or 7 or 8 or 9 or 10 or 11

13. 3 and 12

\section{PsychINFO (to 2005/October)}

\#1 explode "Accident-Prevention" in MJ,MN

\#2 explode "Pedestrian-Accidents" in MJ,MN

\#3 explode "Motor-Traffic-Accidents" in MJ,MN

\#4 explode "Transportation-Accidents" in MJ,MN

$\# 5 \# 1$ or \#2 or \#3 or \#4

\#6 ( (injur* or crash* or accident* or safety or death* or fatalit*) in AB )or( (injur* or crash* or accident* or safety or death* or fatalit*) in TI )

\#7 \#5 or \#6

\#8 explode "Driver-Education" in MJ,MN

\#9 explode "Driving-Behavior" in MJ,MN

\#10 post adj licen*

\#11 driving adj course*

\#12 ( (driv* near (training or improvement or educat* or abilit* or skill* or qualif* or program*)) in AB )or( (driv* near (training or improvement or educat* or abilit* or skill* or qualif* or program*)) in TI )

$\# 13 \# 8$ or \#9 or \#10 or \#11 or \#12

Post-licence driver education for the prevention of road traffic crashes (Review)

Copyright (@) 2008 The Cochrane Collaboration. Published by John Wiley \& Sons, Ltd. 
$\# 14 \quad \# 7$ and \#13

\#15 explode "Clinical-Trials" in MJ,MN

\#16 explode "Meta-Analysis" in MJ,MN

\#17 ((clinical or random* or control*) near trial*) in AB )or( ((clinical or random* or control*) near trial* $\left.{ }^{*}\right)$ in TI $)$ )

\#18 (meta?analys*) in AB) or (meta?analys*) in TI )

$\# 19 \# 15$ or \#16 or \#17 or \#18

$\# 20 \# 14$ and \#19

ERIC 1966 to 2005/October

1. "driver education" in de

2. "driver training" in de

3. 1 OR 2

4. driv* AND (improve* OR program* OR training)

5. 3 OR 4

6. accident prevention in de

7. injur* or crash* or accident* or safety or death* or fatalit*

8. 6 OR 7

9. trial* OR evaluat* OR "meta analysis"

10. 5 AND 8 AND 9

C2-SPECTR (searched October 14, 2005)

1. driver or driving

\section{WHAT'S NEW}

Last assessed as up-to-date: 11 March 2003.

\begin{tabular}{l|l|l}
\hline Date & Event & Description \\
\hline 14 October 2005 & Amended & $\begin{array}{l}\text { The searches were updated and further potentially eligible studies have been added as 'studies awaiting } \\
\text { assessment'. We aim to have the this further research included/excluded and the update complete } \\
\text { in time for issue 2/2006 of The Cochrane Library. }\end{array}$ \\
\hline
\end{tabular}

\section{H IS T O R Y}

Protocol first published: Issue 3, 2002

Review first published: Issue 3, 2003

\begin{tabular}{lll}
\hline Date & Event & Description \\
\hline 19 April 2008 & Amended & Converted to new review format. \\
\hline 12 March 2003 & New citation required and conclusions have changed & Substantive amendment \\
\hline
\end{tabular}




\section{CONTRIBUTIONSOFAUTHORS}

KK helped to design the protocol, screen records, obtain reports, extract data and write the review. IR helped to design the protocol and write the review. TC performed the analyses and commented on the review. FR designed the search strategy, helped to obtain records, extract data and assess methodological quality. FB helped to design the protocol, screen records and extract data.

\section{DECLARATIONS OF INTEREST}

The Head of Occupational Safety of the pharmaceutical company AstraZeneca commissioned this systematic review and provided extramural support. This contribution was in response to a BMJ editorial calling for an evidence-based approach to road safety policy. Also, road traffic crashes are currently the company's leading cause of occupational injury and strategies to reduce the traffic crash involvement of its employees are considered of high priority. This systematic review has not involved any of AstraZeneca's products.

\section{SOURCES OF SUPPORT}

\section{Internal sources}

- No sources of support supplied

\section{External sources}

- AstraZeneca, UK.

\section{NOTES}

Olivier Dupurrex co-ordinated the editorial process as an external editor.

\section{INDEX TERMS}

\section{Medical Subject Headings (MeSH)}

Accidents, Traffic [* prevention \& control]; Automobile Driving [*education]; Licensure; Randomized Controlled Trials as Topic

\section{MeSH check words}

Humans 